NIST Special Publication 1603

\title{
Comparing the Energy and Economic Performance of the NIST NZERTF Design across the Mixed- Humid Climate Zone
}

Joshua Kneifel

Eric O'Rear

This publication is available free of charge from: http://dx.doi.org/10.6028/NIST.SP.1603
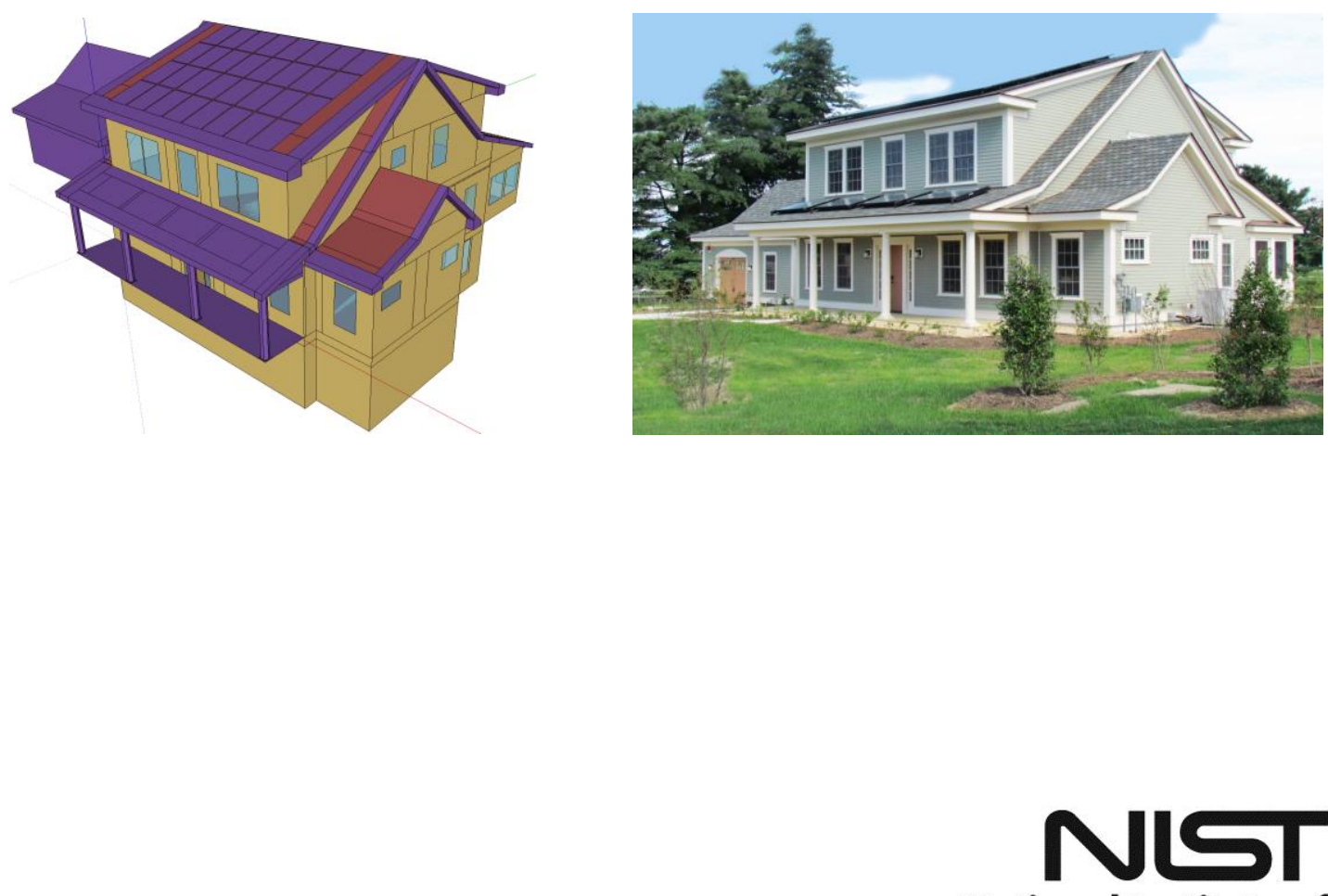

National Institute of Standards and Technology U.S. Department of Commerce 



\title{
Comparing the Energy and Economic Performance of the NIST NZERTF Design across the Mixed- Humid Climate Zone
}

\author{
Joshua Kneifel \\ Eric O'Rear \\ Applied Economics Office \\ Engineering Laboratory
}

This publication is available free of charge from: http://dx.doi.org/10.6028/NIST.SP.1603

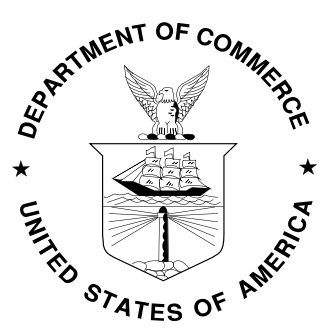

U.S. Department of Commerce Penny Pritzker, Secretary

National Institute of Standards and Technology Willie May, Under Secretary of Commerce for Standards and Technology and Director 
Certain commercial entities, equipment, or materials may be identified in this document in order to describe an experimental procedure or concept adequately. Such identification is not intended to imply recommendation or endorsement by the National Institute of Standards and Technology, nor is it intended to imply that the entities, materials, or equipment are necessarily the best available for the purpose.

National Institute of Standards and Technology Special Publication 1603

Natl. Inst. Stand. Technol. Spec. Pub. 1603, 52 pages (December 2015) http://dx.doi.org/10.6028/NIST.SP.1603

CODEN: NTNOEF 


\begin{abstract}
The National Institute of Standards and Technology (NIST) received funding through the American Recovery and Reinvestment Act (ARRA) to construct the Net-Zero Energy Residential Test Facility (NZERTF). One of the goals of the NZERTF is to demonstrate that a net-zero residential design can "look and feel" like a typical home in the Gaithersburg, MD area. There has been limited evaluation to date on the use of wholebuilding simulation models to evaluate the sensitivity of a unique net-zero energy building design's energy performance to varying weather conditions across multiple locations. Whole-building simulation software such as EnergyPlus $(E+)$, allows the user to simulate the annual energy performance for a specific building design. The purpose of this report is to evaluate both the energy and economic performance of the NZERTF across the Building America Mixed-Humid Climate Zone, using the results of E+. Additionally, the NZERTF design is compared to code compliant designs for 45 locations throughout the climate zone.
\end{abstract}

\title{
Keywords
}

Energy efficiency; net zero energy; residential buildings; whole building energy simulation; life-cycle cost 


\section{Preface}

This study was conducted by the Applied Economics Office (AEO) in the Engineering Laboratory (EL) at the National Institute of Standards and Technology (NIST). The study is designed to compare the energy and economic performance of the NZERTF design to comparable code-compliant building designs for 45 locations throughout the Building America Mixed-Humid Climate Zone designation, using the results of EnergyPlus $(E+)$ whole building energy simulations and life-cycle costing. The intended audience includes researchers in the residential building sector concerned with net-zero energy residential performance.

\section{Disclaimers}

The policy of the National Institute of Standards and Technology is to use metric units in all of its published materials. Because this report is intended for the U.S. construction industry that uses U.S. customary units, it is more practical and less confusing to include U.S. customary units as well as metric units. Measurement values in this report are therefore stated in metric units first, followed by the corresponding values in U.S. customary units within parentheses. 


\section{Acknowledgements}

The authors wish to thank everyone for their advice and recommendations for the writing of this report, including Mr. David Webb and Dr. Robert Chapman of EL's Applied Economics Office, Dr. Lisa Ng of EL's Energy and Environment Division, and Dr. Nicos S. Martys of EL's Materials and Structural Systems Division.

\section{Author Information}

Joshua D. Kneifel

Economist

National Institute of Standards and Technology

100 Bureau Drive, Mailstop 8603

Gaithersburg, MD 20899-8603

Tel.: 301-975-6857

Email: joshua.kneifel@nist.gov

Eric G. O'Rear

Economist

National Institute of Standards and Technology

100 Bureau Drive, Mailstop 8603

Gaithersburg, MD 20899-8603

Tel.: 301-975-4570

Email: eric.orear@nist.gov 


\section{Table of Contents}

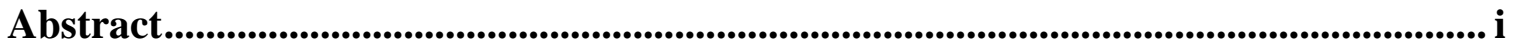

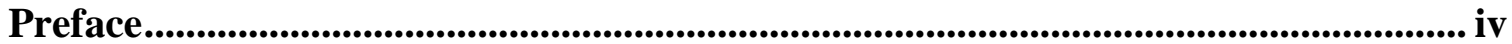

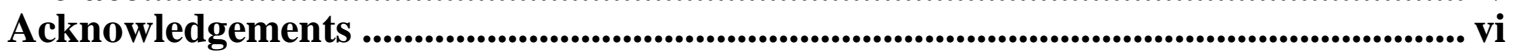

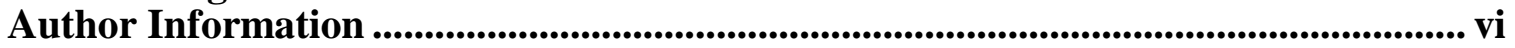

List of Acronyms ................................................................................................................. xii

1 Introduction .................................................................................................................... 1 1

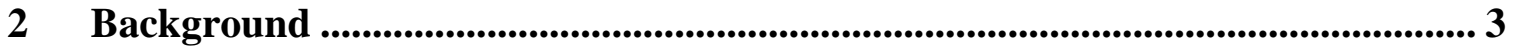

2.1 The Building America Climate Zone Designations ........................................ 3

2.2 Literature Review ..................................................................................... 4

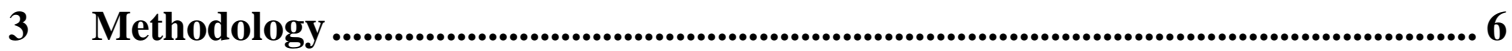

$3.1 \quad$ NIST Net-Zero Energy Residential Test Facility .................................... 6

3.2 The NZERTF Simulation Model Assumptions and Specifications ................... 6

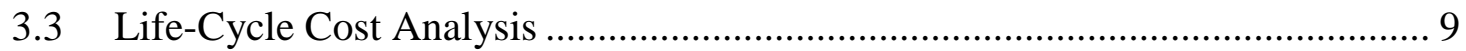

4 Results and Discussion........................................................................................ 11

4.1 Energy Performance of the NZERTF across the Mixed-Humid Climate Zone. 11

4.2 Economic Performance of the NZERTF across the Mixed-Humid Climate Zone

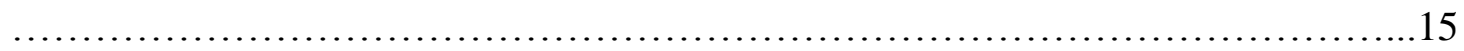

4.3 Comparing the Energy Performance of the NZERTF to a Comparable Code-

Compliant Design ............................................................................................. 18

4.4 A Comparison of the Economic Performances for the NZERTF and Comparable

Code-Compliant Design .................................................................................. 22

5 Discussion, Limitations, and Further Research Opportunities ........................... 25

5.1 Energy and Economic Performance of the NZERTF across the Mixed-Humid

Climate Zone ................................................................................................ 25

5.2 Comparing the Energy and Economic Performance of the NZERTF to a

Comparable Code-Compliant Design ............................................................... 26

5.3 Limitations and Future Research.................................................................. 27

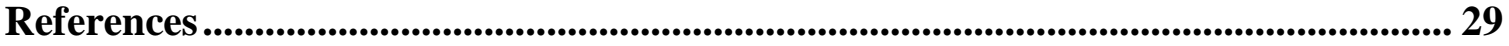

A Appendix......................................................................................................................... 33 


\section{List of Figures}

Figure 2-1 Building America Climate Zone Designations (taken from Energy Efficiency

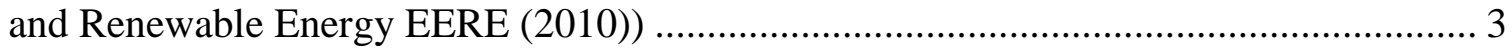

Figure 3-1 NIST Net-Zero Energy Residential Test Facility..................................... 6

Figure 3-2 Selected Cities in the Mixed-Humid Climate Zone ..................................... 7 Figure 4-1 Average Annual Electricity Consumption across the Mixed-Humid Climate

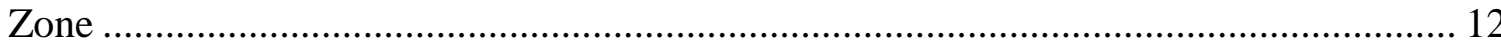

Figure 4-2 Weather-Related Energy Consumption for Select Locations ....................... 13 Figure 4-3 Average Solar PV Production Levels by the NZERTF each Year across the

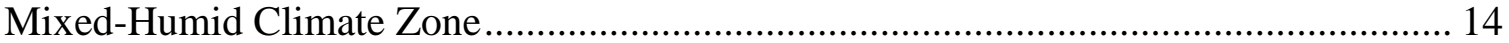
Figure 4-4 Annual Net Energy Production throughout the Mixed-Humid Climate Zone 15 Figure 4-5 Average Construction Costs for the NZERTF Design throughout the Mixed-

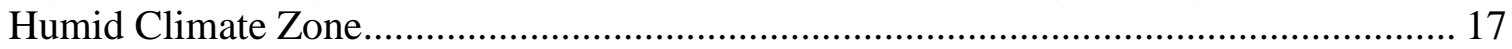
Figure 4-6 Average Energy Costs for the NZERTF throughout the Mixed-Humid Climate Zone (10-year Study Period) ....................................................................... 17 Figure 4-7 Total Life-cycle Costs related to the Building and Operating of the NZERTF Design within the Mixed-Humid Climate Zone (10-year Study Period)........................ 18 Figure 4-8 Adopted IECC Editions in each State as of May 2015 ................................ 19 Figure 4-9 Average Energy Savings (Difference in Energy Use) by Switching from the Code-Compliant to NZERTF Building Design (10-year Study Period) .......................... 20 Figure 4-10 Average Electricity Use for Satisfying the Heating and Cooling Loads of the NZERTF and Code-Compliant Building Designs 21 Figure 4-11 Difference in Average Annual Net Production Levels between the NZERTF and Code-Compliant Building Designs 22 Figure 4-12 Difference in (a) Average Construction Costs and (b) Energy Costs between the NZERTF and Code-Compliant Building Designs ................................................. 23 Figure 4-13 Net Savings (10-Year Study Period) .................................................... 24

\section{List of Tables}

Table 3-1 Net-Zero Energy Residential Test Facility Building Specifications ................ 8 Table A-1 Selected Locations in the Building America Mixed-Humid Climate Zone

Table A-2 Building Specifications under the 2012 and 2105 IECC Editions .......... 34 Table A-3 Building Specifications under the 2009 IECC Edition (Climate Zone 3 and 4 except Marine) Table A-4 Building Specifications under the 2006 IECC Edition (Climate Zone 3 and 4 except Marine) 


\section{List of Acronyms}

\section{Acronym Definition}

$\mathrm{ACH} \quad$ Air Changes per Hour

AEO Applied Economics Office

ARRA American Recovery and Reinvestment Act

ASHRAE American Society of Heating, Refrigerating and Air-Conditioning Engineers

ASTM American Society for Testing and Materials

BA Building America

BSC Building Science Corporation

BIRDS Building Industry Reporting and Design for Sustainability

CDD Cooling Degree Day

CFL compact fluorescent lamp

COP Coefficient of Performance

DOE Department of Energy

DHW Domestic Hot Water

E+ EnergyPlus

EERE Office of Energy Efficiency \& Renewable Energy

EIA Energy Information Administration

EL Engineering Laboratory

ELA effective leakage area

EPA Environmental Protection Agency

HDD Heating Degree Day

HPWH Heat Pump Water Heater

HRV Heat Recovery Ventilator

HSPF Heating Seasonal Performance Facctor

HVAC Heating, Ventilation, and Air-Conditioning

IECC International Energy Conservation Code

LCA Life-Cycle Assessment

LCC Life-Cycle Cost

LCCA Life-Cycle Cost Analysis

LED Light Emitting Diode

NIST National Institute of Standards and Technology

NS Net Savings 


$\begin{array}{ll}\text { Acronym } & \text { Definition } \\ \text { NZERTF } & \text { Net-Zero Energy Residential Test Facility } \\ \text { OC } & \text { on center } \\ \text { MRR } & \text { Maintenance, Repair, and Replacement } \\ \text { PV } & \text { Photovoltaic } \\ \text { SEER } & \text { Seasonal Energy Efficiency Ratio } \\ \text { SHGC } & \text { Solar Heat Gain Coefficient } \\ \text { TMY } & \text { Typical Meteorological Year } \\ \text { VT } & \text { Visual Transmittance }\end{array}$




\section{Introduction}

In 2014 , roughly $41 \%$ of total U.S. energy consumption came from commercial and residential buildings (US Energy Information Administration (EIA) 2015). The growing concerns about energy consumption in buildings - in particular, residential buildings - has driven the U.S. federal, state, and local governments to implement legislation and support initiatives targeting the energy efficiency of the nation's building stock. For example, building codes based on the International Energy Conservation Code (IECC) mandating compliance with minimum energy performance levels for the thermal envelope and systems in new construction have been adopted in order to reduce long-term energy demands. Persistent efforts to tighten building energy codes will gradually increase the overall energy efficiency of the U.S. residential housing market.

Building energy performance is influenced by factors such as weather, heating, ventilation, and cooling (HVAC) equipment efficiency, and building envelope design, and the behavior of its occupants. Of these factors, weather and any associated changes in local climatic conditions have been found to be the most significant and impactful since changes in weather conditions will greatly impact the largest consumer of energy in homes, the HVAC equipment (Hong, Chang et al. 2013a, Hong, Chang et al. 2013b). The same holds true for low-energy homes that rely on solar-based energy generation systems to meet some, or all, of their energy demands. Variation in cloud cover or solar irradiance levels can have noticeable impacts on solar electricity generation. To better understand the relationship between a single building design's energy performance and external factors like weather, building designers often look to simulation software. They have proven beneficial to designers of low-energy consuming home in their efforts to select cost-effective energy-efficiency measures to incorporate in their designs.

A steadily growing interest in low-energy and net-zero energy building designs bring into question how well these types of homes perform under different weather conditions. As climate change continues to alter weather trends, the durability and energy performance of these homes are likely to be tested. In 2012, the National Institute of Standards and Technology (NIST) constructed a single-family net-zero energy house designed to be roughly $60 \%$ more energy efficient than a newly constructed home in the same area built according to the 2012 IECC. The home is capable of producing at least as much energy as it consumes over an entire year. At the end of its first operational year (July 2013 through June 2014), the home proved to not only be net-zero, but also a net energy producer (Kneifel, Payne et al. 2015). Weather conditions during the period were seemingly uncharacteristic for that area with an above average number of days with snow cover being recorded. Despite the energy surplus, it is likely that the unusual weather conditions during that time impacted the home's energy performance, and continued uncertainty in local weather conditions will lead to further performance variability (Kneifel and O'Rear 2015c). To better gauge the robustness of the net-zero designs' performance capabilities under alternative weather conditions, its operation should be simulated throughout various locations, each having climatic conditions that are specific to that location. 
The presence of limited research examining the predicted energy performance of identical buildings across multiple locations with varying weather conditions presents an opportunity to fill this void in the literature. We utilize the U.S. Department of Energy's (DOE's) EnergyPlus v8.3 $(E+)$ whole-building simulation program to compare the energy performance of the NIST Net-Zero Energy Residential Test Facility (NZERTF) design across multiple cities located within the Mixed-Humid climate region designated by the U.S. DOE's Building America Program. The NZERTF is a single-family detached home located in Gaithersburg, Maryland. Annual performance is observed across 45 different cities found in the Mixed-Humid climate region, given the available weather data on these locations captured by Typical Meteorological Year (TMY2 or 4) weather files. The results from the 45 simulations is then used to approximate the average energy and economic performance throughout the entire Mixed-Humid Climate Zone using an interpolation method known as "kriging". Energy performance is evaluated based on total kilowatt-hours of energy use, on-site renewable energy production, and net consumption levels each year. Economic performance is determined based on average construction costs, energy costs, and life-cycle costs. In addition to this, the energy and economic performance of the net-zero design is compared to that of a comparable home built to the IECC requirements that are the basis for the state energy code in each of our selected locations. 


\section{Background}

\subsection{The Building America Climate Zone Designations}

Over the last 20 years, the U.S. Department of Energy's (DOE) Building America Program has worked alongside numerous building industry leaders to improve the energy performance, comfort, durability, quality, and affordability of residential buildings by bringing a number of innovations to the marketplace (U.S. Department of Energy (DOE) 2015). The program incorporates a number of these cutting-edge innovations in their Best Practices guide - a book that guides builders in constructing energy-efficient homes capable of achieving a reduction of at least $30 \%$ in annual household energy use for each of its eight individual climate zones. The purpose of the climate zone designation is to assist builders in their identification of the Best Practices specifications they should adhere to given the location in which they will be building. The climate designations are based on both the International Energy Conservation Code (IECC) and the American Society of Heating, Refrigerating, and Air-Conditioning Engineers (ASHRAE) climate zone specifications. The Hot-Humid, Mixed-Humid, Hot-Dry, Mixed-Dry, Cold, VeryCold, Subarctic, and Marine Building America climate regions are categorized according to the total number of heating degree days (HDDs), average temperatures, and precipitation levels. Figure 2-1 shows seven of the eight climate zone designations (the Subarctic region (Alaska) is not pictured). Because the NZERTF was optimally designed for its location in the Mixed-Humid Climate Zone, our analysis conducts building simulations only in cities located within the Mixed-Humid Climate Zone.

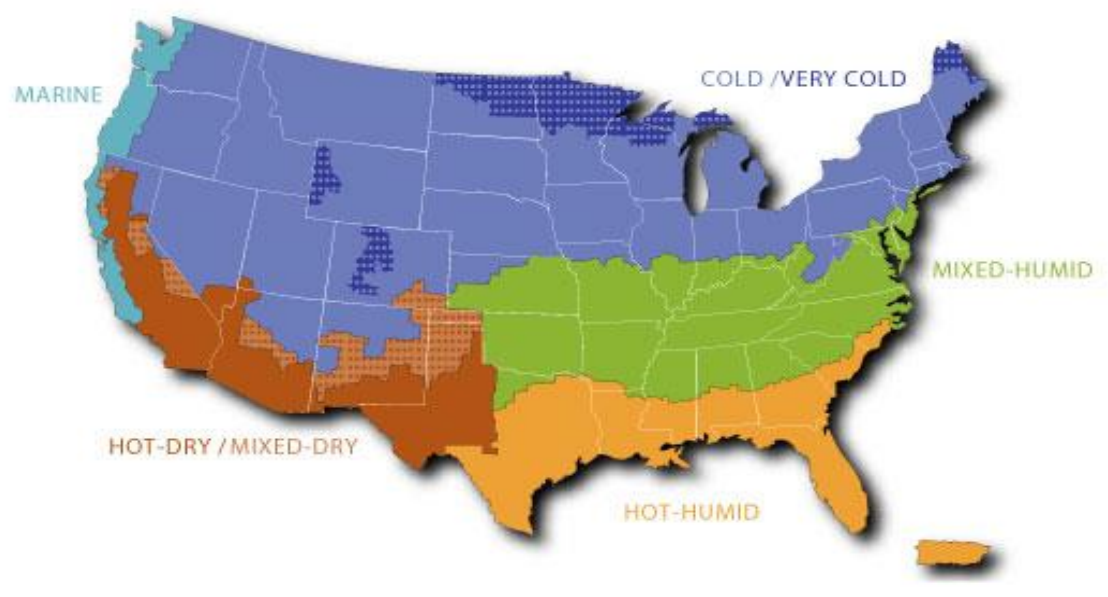

Figure 2-1 Building America Climate Zone Designations (taken from Energy Efficiency and Renewable Energy EERE (2010)) 


\subsection{Literature Review}

Current research analyzing the energy and economic performance of identical energy-efficient building designs across multiple locations is very limited. The literature to date has been focused on comparing the simulated energy performance in different locations for a specific building type designed for the local climate conditions in each location (Lam, Tsang et al. 2006, Lam, Wan et al. 2008, Yang, Lam et al. 2008, Dietrich, Kiehl et al. 2013, Zhang and Zhu 2013). For example, Lam, Wan, et al. (2006) compare the thermal and energy performance for office buildings located in China's five major climate zones (i.e. severe cold, cold, hot summer and cold winter, mild, and hot summer and warm winter). The designs vary according to the building envelope specifications that are specific to the average weather conditions for the zone in which the city is located. They discover that office buildings designed to use the sun's energy to minimize energy consumption by reducing both heating and cooling loads - also referred to as a passive solar design - realize high energy savings in both the severe cold and cold climate zones. In warmer climate zones, however, the benefits of passive solar during the winter months must be balanced out by the negative effects of passive solar on cooling loads during warmer months to minimize energy use. Similarly, Deitrich, Kiehl, et al. (2013) compare the energy performance of alternative zero-energy office space designs across 15 different locations throughout the world. Each building has been "optimized" or modified so that it is suitable for each of the local climates. The energy, heating, and cooling demands of the building are satisfied by on-site geothermal and solar photovoltaic (PV) systems. In most locations, the results suggest that the on-site renewable energy systems do in fact provide a means for the optimized office buildings to either become or come close to becoming a net-zero energy building. Only in the most extreme climates do designs require additional measures to meet the net-zero energy target.

Researchers at NIST have also conducted studies evaluating the energy performance of alternative building designs in different climate zones (Kneifel 2013, Kneifel 2013a, Kneifel and O'Rear 2015b). In an evaluation of the Building Industry Reporting and Design for Sustainability (BIRDS) commercial database, Kneifel (2013) compares the energy performance of 11 different prototype commercial buildings in 228 cities across the U. S. based on building energyefficiency improvements in response to changes in state commercial building codes. Kneifel and O'Rear (2015) conduct a similar analysis in which they use the BIRDS residential database to evaluate the impacts of changes in state residential building codes on national energy consumption. Both studies found that improving the energy-efficiency of newly constructed residential and commercial buildings lead to lower US energy consumption. The costs of achieving these reductions, however, are sensitive to study period length.

More closely related to the analysis conducted in this paper is Kneifel and O'Rear's comparison of the sustainability performance between the NZERTF and a comparable home built to residential building codes adopted by the state of Maryland (Kneifel and O'Rear 2015). Given the average local weather conditions for Gaithersburg, MD captured by the most recent TMY3 weather file, the NZERTF consumes less energy than the code-compliant alternative. Its roof- 
mounted solar PV system generates more than enough electricity to cover total energy demands for the year making the home not only net-zero but also a net energy producer.

The current building simulation literature sheds light on the energy performance of alternative energy-efficient building designs across different locations. However, there has been a lack of consideration for the simulated performance of a common building design across multiple cities where each city has their own climatic characteristics despite being grouped together under a common climate zone. There has also been limited consideration for any variations in economic performance across the different locations associated with building energy-efficiency improvements. The results of this report will be used to help fill in the apparent gaps in the literature. 


\section{Methodology}

\subsection{NIST Net-Zero Energy Residential Test Facility}

The NZERTF is located on NIST's main campus in Gaithersburg, MD. The two-story, fourbedroom house, shown in Figure 3-1, was initially constructed to show that a residential home design could be net-zero and still have the "look and feel" of a typical home in the area (Pettit and Gates 2014). It has approximately $251.7 \mathrm{~m}^{2}\left(2709 \mathrm{ft}^{2}\right)$ of total conditioned floor area and was designed to be roughly $60 \%$ more energy-efficient than newly constructed homes in the area based on the 2012 IECC. Additionally, a $10.2 \mathrm{~kW}$ solar PV system was installed on the roof to produce more electricity than is consumed over a year. The facility's initial demonstration phase was from July 2013 to June 2014. During this period, the model home proved to not only be net-zero, but a net energy producer with an excess generation of $484.1 \mathrm{kWh}$ (Fanney, Payne et al. 2015).

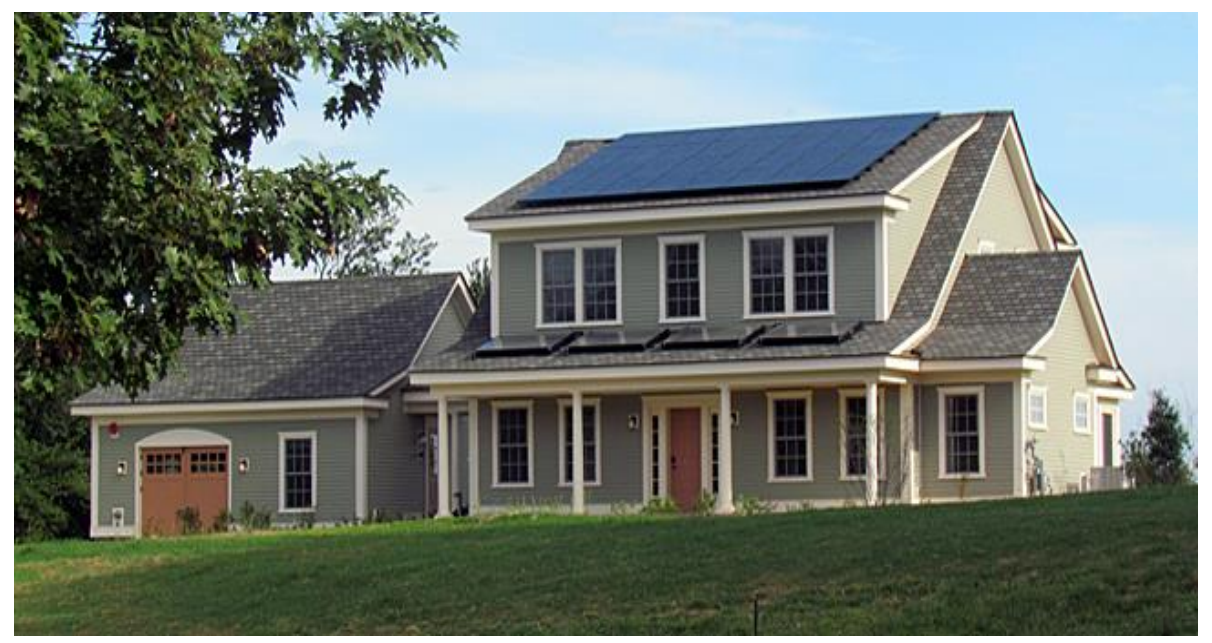

Figure 3-1 NIST Net-Zero Energy Residential Test Facility

\subsection{The NZERTF Simulation Model Assumptions and Specifications}

Evaluation of the energy performance of any building design requires the use of whole-building simulation software. We use the $E+8.3 .0$ whole-building energy simulation program to estimate the annual energy performance of the NZERTF (U.S. Department of Energy (DOE) 2015). Use of this program requires a number of general assumptions, such as the most representative local weather data, time step designations, and run periods. The program also requires the building specifications for the simulated design.

The effects of local weather conditions on the $E+$ program's estimates of the energy consumption and solar PV production by the NZERTF are determined based on meteorological inputs provided by TMY weather files. TMY files are generated using 15 to 30 years of 
historical hourly weather data and serve as the best representation of "typical" weather conditions for a given location. For our analysis, we rely on the most recent iteration of the TMY weather files (TMY3) generated on 15 years (1991 through 2005) of weather data spanning more than 1400 U.S. weather data collection sites. One of the aims of our study is to compare the energy performance of the NIST NZERTF design across multiple cities located in the MixedHumid climate zone. To do so, a TMY3 weather file is selected for each city considered in the analysis. Figure 3-2 displays the selected 45 cities in the Mixed-Humid climate zone for this study. The full list of cities can be found in Table A-1 in the Appendix.

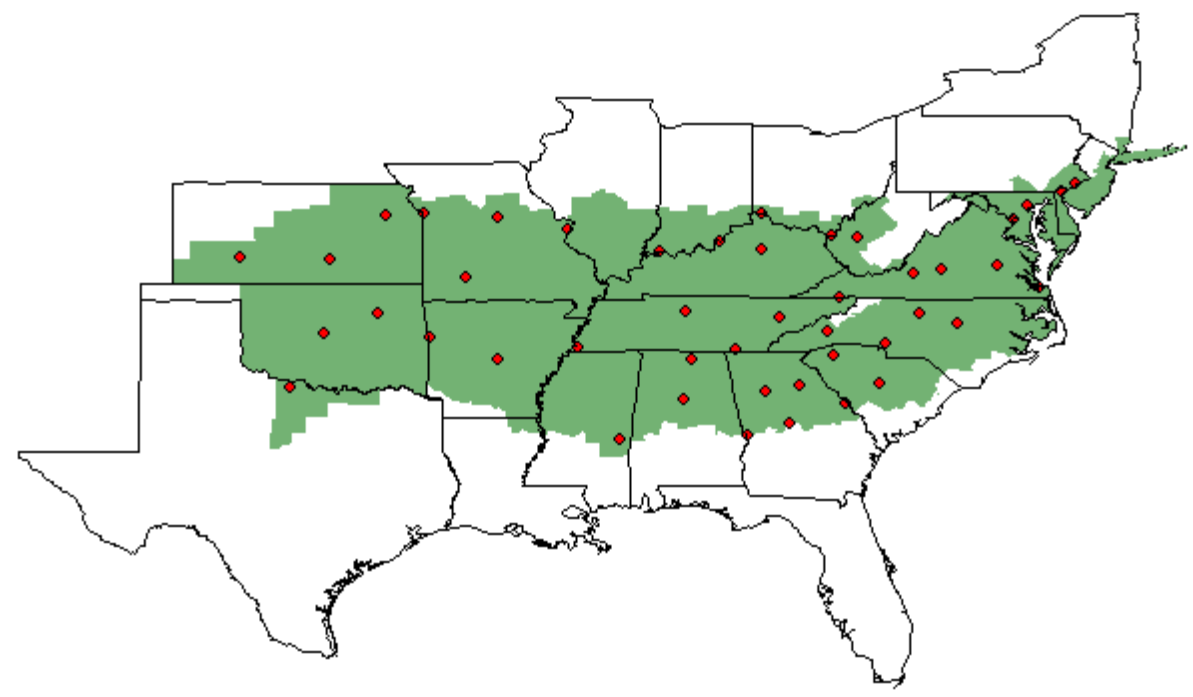

Figure 3-2 Selected Cities in the Mixed-Humid Climate Zone

The $E+$ software requires the user to select a specific run period and time step. A run period is representative of the days of the year the simulation will run, while the time step represents the frequency at which the model runs the simulation. We choose a one-year run because we are observing the impacts of alternative weather conditions on annual energy use and production. A one-minute time-step is chosen due to the assumed length of some household activities (e.g. hot water use by the sink) being modeled in one-minute increments. Use of a one-minute time step allows for a more accurate capturing of system operation and energy consumption (Kneifel 2012).

The NZERTF post-demonstration phase specifications shown in Table 3-1 include details on the building specifications and systems. 
Table 3-1 Net-Zero Energy Residential Test Facility Building Specifications

\begin{tabular}{|c|c|c|}
\hline Building Category & Specifications & Details \\
\hline Windows & $\begin{array}{l}\text { U-Factor } \\
\text { SHGC } \\
\text { VT }\end{array}$ & $\begin{array}{c}1.14 \mathrm{~W} / \mathrm{m}^{2}-\mathrm{K}\left(0.20 \mathrm{Btu} / \mathrm{h} \cdot \mathrm{ft}^{2}-\mathrm{F}\right) \\
0.25 \\
0.40\end{array}$ \\
\hline $\begin{array}{l}\text { Framing and } \\
\text { Insulation }\end{array}$ & $\begin{array}{l}\text { Framing } \\
\text { Exterior Wall } \\
\text { Basement Wall } \\
\text { Basement Floor } \\
\text { Roof }\end{array}$ & $\begin{array}{c}5.1 \mathrm{~cm} \mathrm{X} 10.2 \mathrm{~cm}-40.6 \mathrm{~cm} \mathrm{OC}(2 \text { in X } 6 \text { in }-24 \text { in OC) } \\
\mathrm{R}_{\mathrm{SI}^{-}}-3.5+4.2\left(\mathrm{R}-20+24^{*}\right) \dagger \\
\mathrm{R}_{\mathrm{SI}}-3.9\left(\mathrm{R}-22^{*}\right) \dagger \\
\mathrm{R}_{\mathrm{SI}}-1.76(\mathrm{R}-10) \dagger \\
\mathrm{R}_{\mathrm{SI}^{-}}-7.9+5.3\left(\mathrm{R}-45+30^{*}\right) \dagger\end{array}$ \\
\hline $\begin{array}{l}\text { Building Envelope } \\
\text { Airtightness }\end{array}$ & $\begin{array}{l}\text { Air Change Rate } \\
\text { Effective Leakage } \\
\text { Area }\end{array}$ & $\begin{array}{c}0.61 \mathrm{ACH}_{50} \\
1^{\text {st }} \text { Floor }=98.8 \mathrm{~cm}^{2}\left(15.3 \mathrm{in}^{2}\right) \\
2^{\text {nd }} \text { Floor }=90.2 \mathrm{~cm}^{2}\left(14.0 \mathrm{in}^{2}\right)\end{array}$ \\
\hline Lighting & $\begin{array}{l}\% \text { of Efficient } \\
\text { Lighting }\end{array}$ & $100 \%$ efficient built-in fixtures \\
\hline HVAC & $\begin{array}{l}\text { Heating/Cooling } \\
\text { Outdoor Air** }\end{array}$ & $\begin{array}{l}\text { Air-to-air heat pump (SEER 15.8/HSPF 9.05) } \\
\text { Separate HRV system }\left(0.04 \mathrm{~m}^{3} / \mathrm{s}\right)\left(80 \mathrm{ft}^{3} / \mathrm{min}\right)\end{array}$ \\
\hline Domestic Hot Water & $\begin{array}{l}\text { Water Heater } \\
\text { Solar Thermal }\end{array}$ & $\begin{array}{l}50 \text { gallon heat pump water heater (COP } 2.33 \text { ) } \\
2 \text { panel, } 80 \text { gallon solar thermal storage tank }\end{array}$ \\
\hline Solar PV System & System size & $10.2 \mathrm{~kW}$ \\
\hline
\end{tabular}

The NZERTF's building envelope is constructed to be "tighter" than identical homes built under IECC requirements given the improvements to framing, insulation, windows, and air leakage. It is constructed using $5.1 \mathrm{~cm} \mathrm{X} 15.2 \mathrm{~cm}-61.0 \mathrm{~cm}$ ( 2 in X 6 in -24 in) on center (OC) framing ("advanced framing") as opposed to the traditional $5.1 \mathrm{~cm} \mathrm{X} 10.2 \mathrm{~cm}-40.6 \mathrm{~cm}$ ( 2 in X 4 in -16 in) OC framing. Thicker framing decreases the amount of wood used in framing the house, while allowing for more insulation within the wall cavity, potentially improving the overall thermal performance of the home (Lstiburek and Eng 2010). The exterior wall uses R-20 in the wall cavity plus an additional R-24 of rigid insulation. The interior of the basement wall uses R-10 plus an additional R-12 of rigid insulation. Construction of the roof includes R-45 insulation in the rafters with rigid insulation R-30 added to the exterior of the roof.

The U-Factor, Solar Heat Gain Coefficient (SHGC), and the Visible Transmittance (VT), are used in the simulation to describe the fenestration surface construction materials for windows. The values listed in Table 3-1 are based on minimum requirements specified in the 2012 IECC and the Building Science Corporation (BSC) window specifications (Building Science Corportation (BSC) 2009). 
The measure of building envelope airtightness for the NZERTF is characterized by a series of pressurized and depressurized blower door tests conducted according to ASTM E779-10 (ASTM International 2010). The building envelope airtightness was determined to be 0.63 air changes per hour $\left(\mathrm{h}^{-1}\right)$ at $50 \mathrm{~Pa}\left(\mathrm{ACH}_{50}\right)$. The air changes per hour were converted into effective leakage area (ELA) and split between the first and second floor of the simulated design based on the fraction of volume because the use of ELA leads to more accurate simulation results as it accounts for varying infiltration rates linked to the stack effect and wind affect for changes in weather (Kneifel, Payne et al. 2015).

All electrical and mechanical systems in the house are energy efficient. All light fixtures in the NZERTF are high-efficiency with the use of compact fluorescent (CFL), linear fluorescent, and light emitting diode (LED) bulbs. The HVAC system consists of a high-efficiency heat pump to meet the heating and cooling loads of the home and a standalone heat recovery ventilator (HRV) with separate duct system operating year-round to meet any mechanical ventilation requirements. The household domestic hot water (DHW) system includes a 50-gallon heat pump water heater (HPWH) with a coefficient of performance of 2.33 and an electric back-up with a thermal efficiency of 0.98. It also uses two solar thermal panels and an 80-gallon storage tank to preheat water entering the HPWH. The on-site renewable energy generation system is a $10.2 \mathrm{~kW}$ solar PV system, which was the largest system that could be installed given the roof dimensions. For additional details on the NZERTF simulation design specifications and general assumptions, refer to Kneifel, Payne et al. (2015).

\subsection{Life-Cycle Cost Analysis}

The life-cycle cost analysis (LCCA) performed in this study is based on the American Society for Testing and Materials (ASTM) International standard method for life-cycle costing of building related investments (ASTM International 2012). This costing approach serves as a method to evaluate different projects given all of the costs associated with owning, operating, maintaining, and disposing of a project (Fuller and Petersen 1996). The ASTM International standard (ASTM E917) involves calculating a stream of cash flow's present value by discounting its future value into today's dollars based on the year the cash flow occurs and the assumed discount rate. Total life-cycle cost (LCC) equals the sum of the present value of all relevant cash flows, both positive and negative.

The life-cycle costs based on constructing and operating the NZERTF building design include construction or first costs ( Cost $\left._{\text {First }}\right)$, the present value of energy costs ( Cost $\left._{\text {Energy }}\right)$, the present value of maintenance, repair, and replacement costs $\left(\operatorname{Cost}_{M R R}\right)$, and the present value of the residual value $(R V)$ of the building and many of its energy-efficient components (e.g. solar PV system). The sum of individual LCC components are shown in Equation (1) below:

$$
L C C=\text { Cost }_{\text {First }}+\text { Cost }_{\text {Energy }}+\text { Cost }_{M R R}-R V
$$


The first cost component is the sum of all construction costs. It includes the incremental costs of all energy-efficient measures that have been integrated into the building's design. Energy costs are the present value of all monies spent on energy consumed by the household. The discounted costs of all future maintenance, repair, and replacement (MRR) of individual building components associated with the building's operation are captured in the MRR cost component. Lastly, the present value of the residual or "resale" value component accounts for the building's worth at the end of the study period. Houses generally have a much longer anticipated lifetime than the amount of time in which an owner inhabits the home. As a result, there will be some value associated with the house at the time of resale.

In comparing the life-cycle costs of the NZERTF design to that of a comparable code-compliant design throughout different locations in the Mixed-Humid climate zone, we rely on another economic performance metric, Net Savings. Net Savings (NS), as shown in Equation (2), is the difference between the $\mathrm{LCC}$ for the code-compliant design ( $\left.L C C_{\text {Compliant }}\right)$ and the $\mathrm{LCC}$ for the NZERTF design $\left(L C C_{N Z E R T F}\right)$. A difference greater than zero implies that the NZERTF design is the more cost-effective alternative.

$$
N S=L C C_{\text {Compliant }}-L C C_{N Z E R T F}
$$




\section{Results and Discussion}

To gauge the overall performance of the NIST net-zero energy building design, two performance measures are considered: (1) energy performance (Section 3.2); and (2) economic performance (Section 3.3). Results discussed in Section 4.1 and Section 4.2 are based on a comparison of the energy and economic performance of the NZERTF building design across 45 different cities located within the Mixed-Humid Climate Zone. These results are interpolated and extrapolated throughout the entire climate zone using a spatial analysis technique known as "kriging". Kriging estimates a variable at an unknown location based on observed values at surrounding locations (Bohling 2005). Unlike many other interpolation processes, it determines the value of each unknown variable by using a data-driven weighting function when summing over values at neighboring locations. Section 4.3 and Section 4.4 evaluate differences in the energy and economic performance between the NZERTF design and a comparable building design constructed for the location's state energy code, which is based on a particular edition of IECC. Similar to the previous sections, comparisons are done for all 45 locations before being interpolated and extrapolated throughout the Mixed-Humid climate zone. As is required under LCC methodology, all costs are given in present value dollars.

\subsection{Energy Performance of the NZERTF across the Mixed-Humid Climate Zone}

The average annual energy consumption by the NZERTF throughout the Mixed-Humid Climate Zone is shown in Figure 4-1. The greatest consumption (12 $608 \mathrm{kWh}$ to $12865 \mathrm{kWh}$ ) occurs in states located in the western portion of the region (i.e. Oklahoma, Kansas, Missouri, Arkansas, and Mississippi). Portions of South Carolina, North Carolina, West Virginia, Virginia, Tennessee and Kentucky, realize the least amount of electricity use with average yearly consumption falling within the $11689 \mathrm{kWh}$ to $11975 \mathrm{kWh}$ range. Even within the same climate zone, annual energy consumption varies by up to $1176 \mathrm{kWh}$. 


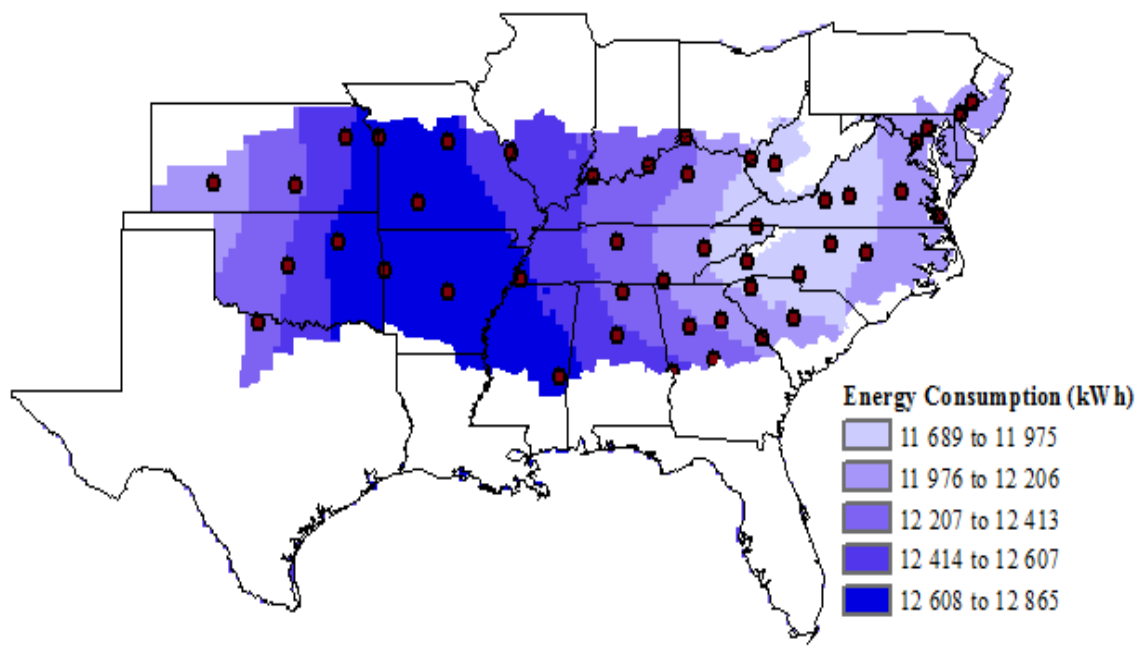

\section{Figure 4-1 Average Annual Electricity Consumption across the Mixed-Humid Climate Zone}

The electricity consumption trends seen in Figure 4-1 are primarily driven by differences in the heating and cooling loads across the various locations. Existing weather data from the 2013 ASHRAE Handbook reveals that many of the cities located within the highest consumption band have either a significantly greater number of Heating Degree Days (HDDs) or both Heating Degree Days and Cooling Degree Days (CDDs), than other cities in the Mixed-Humid Climate Zone (ASHRAE Handbook 2013). A HDD (CDD) relates the day's temperature to the amount of energy needed to heat (cool) the conditioned space(s). According to the ASHRAE Handbook, cities located in Arkansas, Mississippi, Texas, and Oklahoma, on average, realize a noticeably higher number of CDDs than other portions of the climate zone. The additional energy needed to satisfy higher cooling loads in these areas result in average annual electricity consumption totaling $12622 \mathrm{kWh}$ or more. High electricity consumption in Missouri and Kansas are traceable back to the high numbers of both HDDs and CDDs.

The northeast portion of the Mixed-Humid Climate Zone is generally cooler for larger portions of the year compared to other areas in the climate zone. Large heating loads that are characteristic of the area have the potential to significantly impact energy use. Low consumption levels witnessed in Figure 4-1 suggests that the NZERTF, given its current building specifications, performs best in North Carolina and in the northeast region of the climate zone. Homes located in colder climates typically consume more energy than those in warmer climates because heating loads tend to dominate, with the opposite expected for homes located in warmer climates. However, our simulation results reveal that even in the coolest portions of the climate zone, the electricity used for air conditioning plays a much larger role in the NZERTF's total energy consumption than heating-based electricity use. This outcome is directly related to the thermal performance (i.e. tightness and insulation levels) of the NZERTF's building envelope, which significantly lowers the amount of energy needed to satisfy household heating loads while slightly increasing cooling loads. Not only is there less energy transfer through the building 
envelope, but the heat gains from equipment and occupant loads remain within the building. In the northeast portion of the climate zone, electricity required for heating is much lower than electricity required for cooling.

Figure 4-2 shows a breakdown of the energy used by the HVAC system for selected locations (both heating- and cooling-dominated) across the Mixed-Humid Climate Zone. The energy used for cooling is noticeably higher than energy used for heating in almost all cases. Atlanta and Memphis are the largest consumers of the group, which are the most cooling-dominated cities considered. Cities located near Evansville, IN are large energy consumers as well due to the combination of large cooling and heating loads.

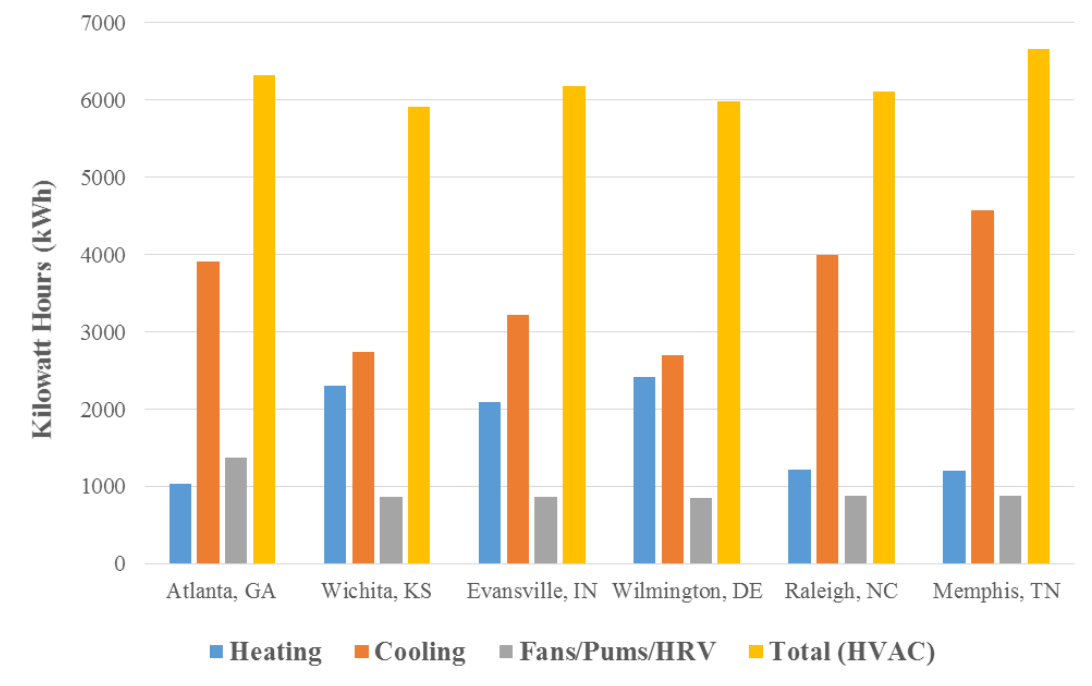

Figure 4-2 Weather-Related Energy Consumption for Select Locations

Figure 4-3 shows that yearly average solar electricity generation trends do not mirror consumption trends witnessed in Figure 4-1 and vary significantly across the climate zone. Average production is greatest in the western-most portions of the climate zone. Texas, Oklahoma, and Kansas realize an annual average production of at least $16374 \mathrm{kWh}$. This is closely followed by Alabama, Georgia, and South Carolina with average annual production levels in large portions of each state falling within the $16374 \mathrm{kWh}$ to $17057 \mathrm{kWh}$ range each year. 


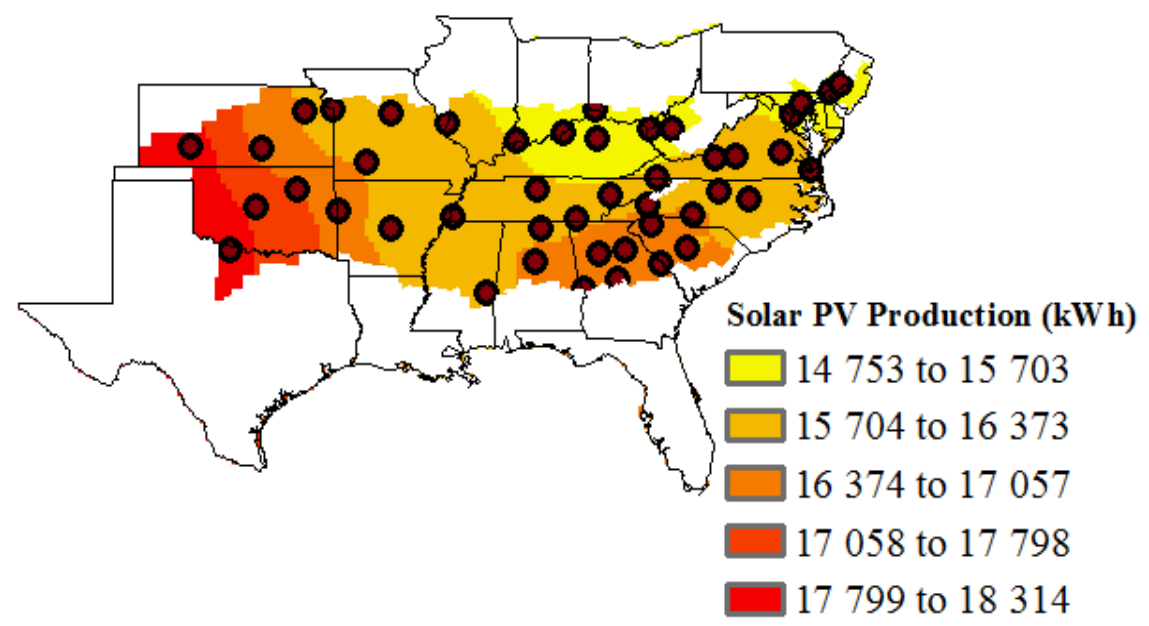

\section{Figure 4-3 Average Solar PV Production Levels by the NZERTF each Year across the Mixed-Humid Climate Zone}

There are three key factors driving these results. First, PV systems generally perform better further south because the average Global Horizontal Irradiance (GHI) levels increase, which equates to higher production levels (National Renewable Energy Laboratory (NREL) 2015). Another factor impacting production is system positioning (i.e. tilt). Optimal tilt positioning - tilt that leads to greatest production - will be such that it equals the latitudinal coordinates of the system's location. The current orientation and tilt of the NZERTF's solar PV system is true south and $18.4^{\circ}$ from the horizontal. The system tilt is well below the optimal tilt angle $\left(30.1219^{\circ} \mathrm{N}\right)$ based on the latitudinal coordinate of Gaithersburg, MD. As expected, Figure 4-3 shows that system performance improves the further south the location of the NZERTF, as the system's tilt angle grows closer to the latitudinal positioning of the PV system.

The final contributing factor is cloud cover, which reduces the amount of GHI that reaches the system panels preventing systems from producing their full rated capacity level. Data on sky cover (given as "\% Sky Cover") for each of the 45 locations were retrieved from their respective TMY3 weather files (U.S. Department of Energy (DOE) 2015). Hourly values are aggregated up to an average percentage of annual sky cover for each location, which are then averaged to provide yearly average sky cover at the state level. Derived state averages reveal that the northeast portion of the climate zone experiences the greatest amount of cloud cover, followed by states located in the southeast. The least amount of annual sky cover occurs in the westernmost portion of the climate zone. Sky cover trends match production trends in Figure 4-3. Solar irradiance, latitudinal positioning, and cloud cover each impact electricity production differently, with the combination of the three ultimately dictating production levels for a location.

Measurements of net energy production combine consumption and production to determine the average excess electricity generated by the NZERTF for a typical year. Figure 4-4 shows that the NZERTF design will consistently be a net energy producer throughout the entire climate zone. 
The portions of Texas, Oklahoma, and Kansas that are located in the Mixed-Humid Climate Zone, are the largest net producers with average net production between $3891 \mathrm{kWh}$ to $5788 \mathrm{kWh}$ each year. The smallest net producers are found in Illinois, Indiana, Kentucky, Maryland, Pennsylvania, and Delaware with annual net production levels of $3890 \mathrm{kWh}$ or less. Comparing Figure 4-3 and Figure 4-4 unveils a positive relationship between solar electricity generation and net production driven by the fact that production has a greater magnitude of variability. The larger solar generating states are also the largest net producers (e.g. Oklahoma and Texas). Conversely, the smaller net producers realize the least amount of annual solar PV generation.

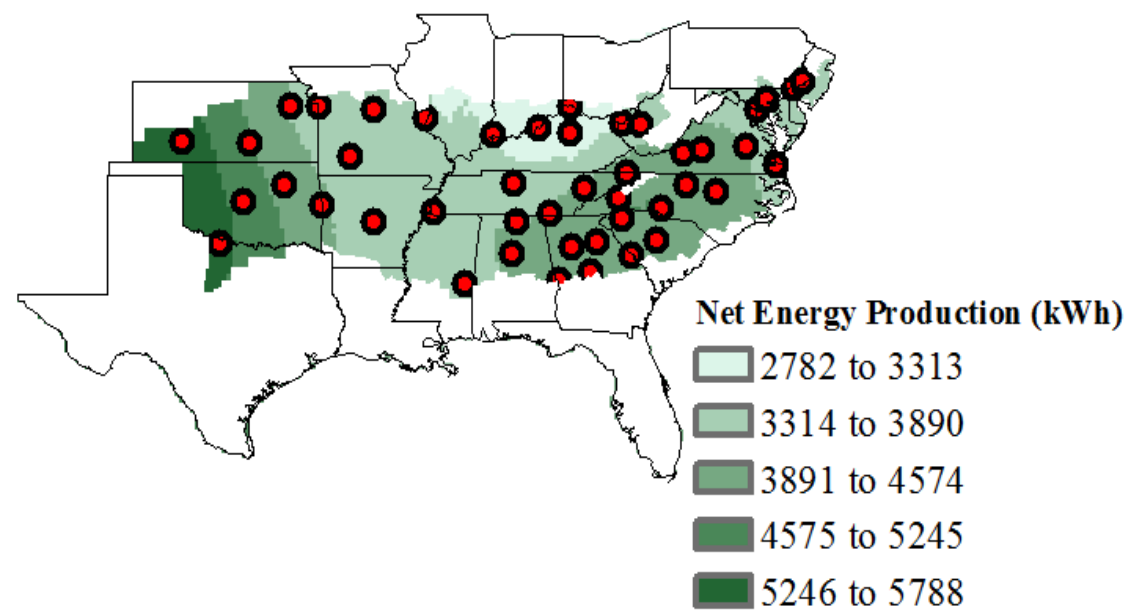

Figure 4-4 Annual Net Energy Production throughout the Mixed-Humid Climate Zone

Our findings thus far suggest that the differences in local climatic conditions produce greater variability in solar PV production than building energy consumption. The high efficiency of the NZERTF design ensures that it performs (i.e. consumption) consistently across different weather conditions.

Basing overall energy performance on measures of net energy production, the above results suggest that the NZERTF design is likely to perform best in cities located in the western-most portions of the Mixed-Humid Climate Zone. In fact, the predicted energy performance of the building is better in these states than it is in the state of Maryland where the actual building structure is located.

\subsection{Economic Performance of the NZERTF across the Mixed-Humid Climate Zone}

Energy performance alone does not paint a full picture of building performance. Other factors such as the costs associated with constructing and operating the building must also be considered. This section examines the economic performance of the NZERTF building design throughout the Mixed-Humid region by considering building construction costs, operating costs, and life-cycle costs. All values are given in present value dollars under the assumption of a $3 \%$ discount rate(Kneifel and Lavappa 2015)(Kneifel and Lavappa 2015)(Kneifel and Lavappa 
2015)(Kneifel and Lavappa 2015)(Kneifel and Lavappa 2015)(Kneifel and Lavappa 2015)(Kneifel and Lavappa 2015) ${ }^{1}$.

The additional expense of incorporating energy conserving technologies and on-site renewable energy generation makes constructing a net-zero home considerably more costly than building a comparable design in the same location without the additional energy-efficiency measures. Kneifel and O'Rear (2015) found that constructing a home based on the NIST's NZERTF design in Gaithersburg, MD would cost the homeowner an additional $\$ 100000$ when compared to the costs of constructing a comparable home built according to the 2012 IECC regulations in that state. Since construction costs vary across the U. S., the cost associated with building the netzero design will vary across Mixed-Humid Climate Zone.

Figure 4-5 displays the average cost of constructing the NZERTF in different locations throughout the climate zone. Our total cost estimates for constructing a building in a particular city include the costs of labor, materials, equipment, overhead, and profit. For the NZERTF design in particular, construction costs are calculated by summing over the costs of the baseline building (based on national average construction costs) and the incremental costs associated with improving the home's building envelope, HVAC system, domestic hot water system, and the integration of the solar PV system. These costs are then adjusted using a city construction cost index (Faithful+Gould 2011, Faithful+Gould 2012). Following the indexing of these costs, they are once again adjusted for contractor and architect profits by multiplying the index costs by average "mark-up" rates for both the contractor and architect. Information on the construction cost calculation approach used in this paper can be found in the BIRDS New Residential Database Technical Manual (Kneifel and Lavappa 2015). For data on the incremental costs of the additional energy-efficiency measures adopted by the NZERTF design, please refer to (Faithful+Gould 2012, Barbose, Weaver et al. 2014).

According to the construction cost indexes or "location factors" for the 122 urban locations calculated by Faithful+Gould (2012), scaling of total national average construction costs increases the further north within the Mixed-Humid Climate Zone you travel. In other words, building the NZERTF will be less costly in the southern portion (less than $\$ 500$ 000) of the climate zone and will grow more costly as you move northward (around $\$ 550000$ ). Figure 4-5 reflects this relationship between location and construction costs showing that average construction costs continue to increase from south to north. Construction is most expensive in Missouri, Illinois, and Indiana given their high location factors.

\footnotetext{
${ }^{1}$ The $3 \%$ discount rate is based on the most recent estimate of the nominal discount rate determined by the Department of Energy, and is used in LCC analyses for federal projects related to energy conservation, renewable energy sources, and water conservation.
} 


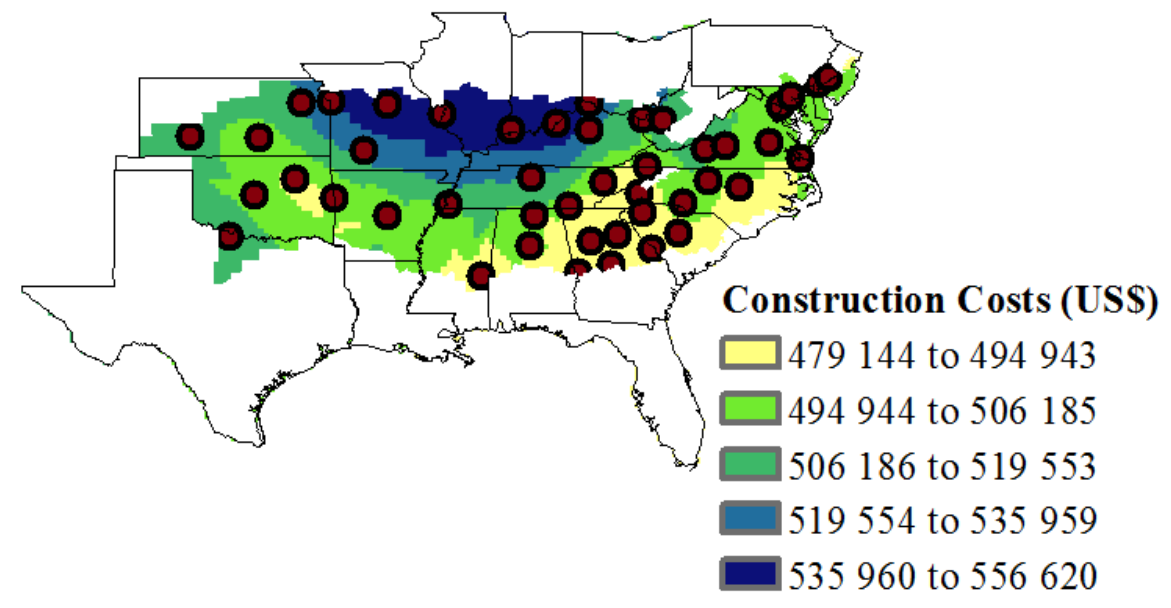

Figure 4-5 Average Construction Costs for the NZERTF Design throughout the MixedHumid Climate Zone

Figure 4-6 displays the average electricity expenditures for the NZERTF under the assumption of a 10-year study period ${ }^{2}$ throughout the Mixed-Humid climate zone. Energy costs are consistently negative, implying a savings in annual energy costs across the entire climate zone. Unlike Figure 4-5, there appear to be no apparent trend in energy costs. For example, areas recouping cost savings between $-\$ 4876$ to $-\$ 6329$ are realized in small clusters inconsistently distributed throughout the climate zone. Steering the variability in energy costs shown in Figure 4-6 are the differences in state energy prices and/or energy consumption profiles.

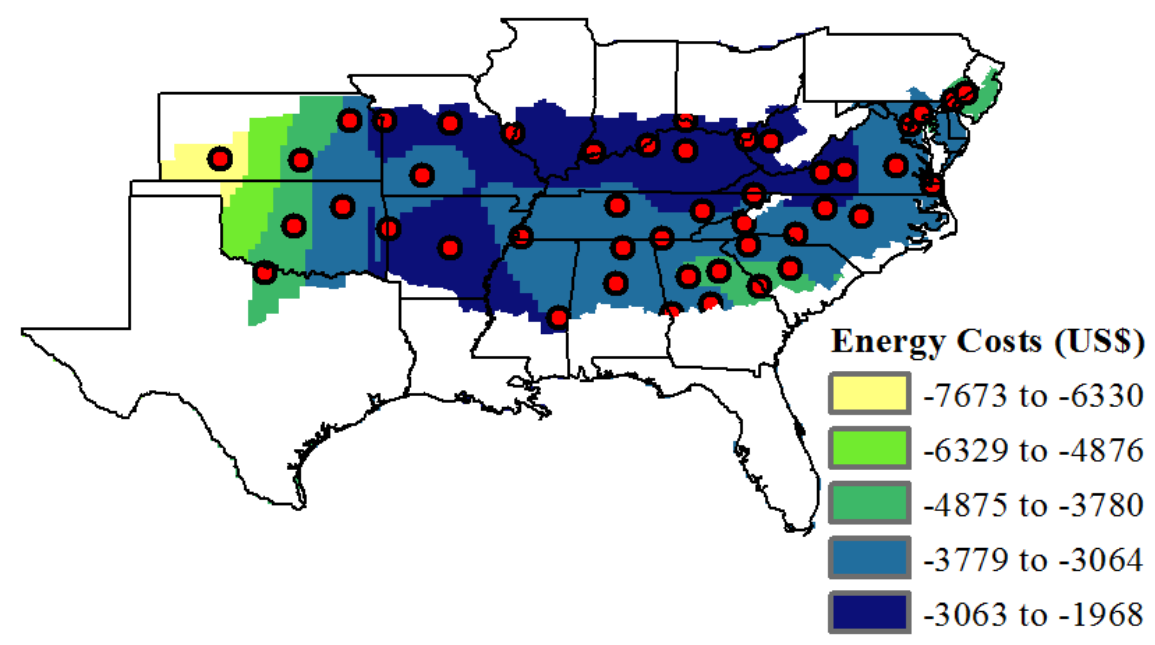

Figure 4-6 Average Energy Costs for the NZERTF throughout the Mixed-Humid Climate Zone (10-year Study Period)

\footnotetext{
${ }^{2}$ A recent article published by the National Association of Homebuilders (NAHB) found that the typical buyer of single-family dwelling will live in the home for an average of 13 years before moving out; therefore, we assume a 10 -year study period in the calculation of energy and life-cycle costs.
} 
The LCC for a building design includes all of the relevant costs (i.e. construction costs, energy costs, MRR, and residual value) related to the building's construction and operation over the study period (10 years). It also includes the federal tax credit earned if the design includes the 10.2 kW solar PV system. Figure 4-7 shows the distribution of LCC throughout the MixedHumid Climate Zone for a 10-year study period. Falling between \$203 853 and \$220 283, average LCC (for a 10-year study period) is highest in Missouri, Illinois, Indiana, and Kentucky. LCC diminish as you move further south within the climate zone. Trends in LCC are largely consistent with construction cost trends witnessed in Figure 4-5. Construction costs vary by roughly $\$ 77000$ while energy costs (Figure 4-6) vary by $\$ 9600$ for a 10 -year study period; therefore, it is the construction costs driving the variability in LCC. The significance or weight of construction costs in the total LCC calculation is highly dependent on the assumed study period length. With longer study periods it is likely that LCC trends will start to mirror energy cost trends.

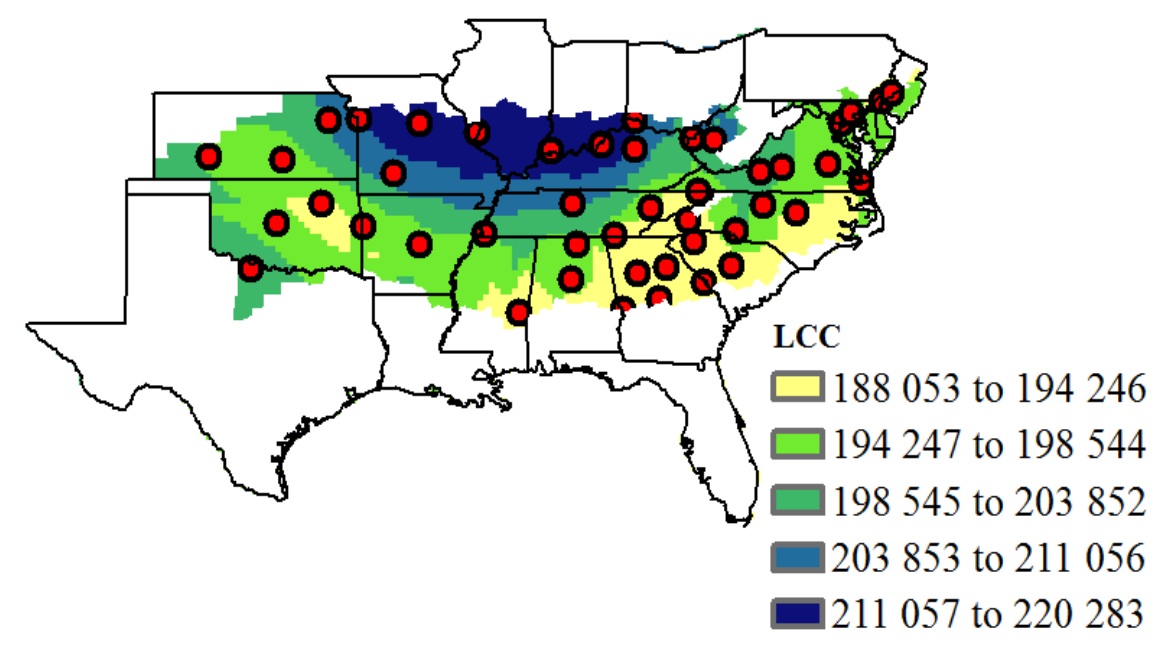

Figure 4-7 Total Life-cycle Costs related to the Building and Operating of the NZERTF Design within the Mixed-Humid Climate Zone (10-year Study Period)

\subsection{Comparing the Energy Performance of the NZERTF to a Comparable Code- Compliant Design}

In their work comparing the simulated performance of the NZERTF to a Maryland codecompliant design, Kneifel and O'Rear (2015) discovered that the code-compliant design consumes more than twice the electricity used by the NZERTF for a typical year in Gaithersburg, MD. With the addition of the $10.2 \mathrm{~kW}$ solar PV system integrated into its design, the electricity generated by the NZERTF more than offsets annual household consumption resulting in a production surplus of more than $4000 \mathrm{kWh}$. This section of our analysis builds upon this work by expanding the evaluation of differences in energy performance between the NZERTF and an alternative code-compliant design across the entire Mixed-Humid Climate Zone. Consideration 
is given for the different IECC editions adopted by each state. The most up-to-date state energy codes are shown in Figure 4-8.

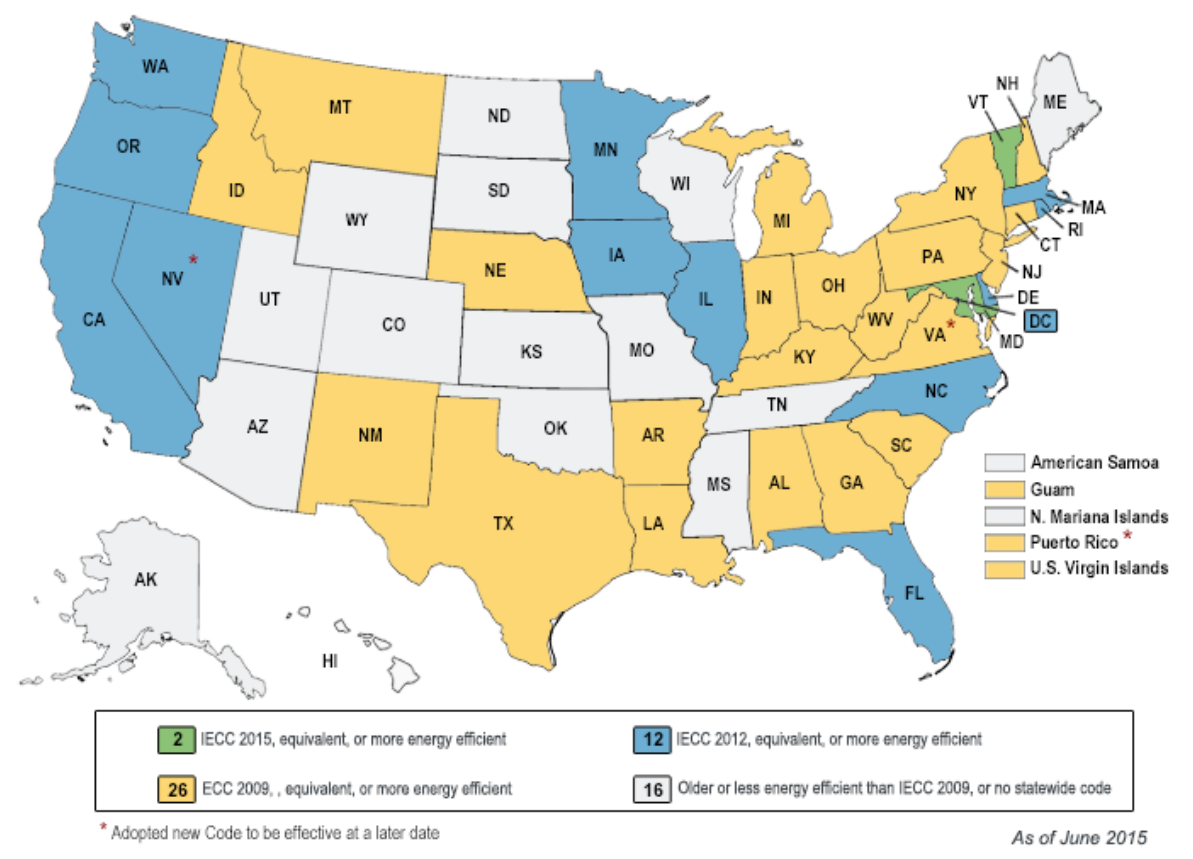

Figure 4-8 Adopted IECC Editions in each State as of May 2015 3

The NZERTF and the code-compliant designs in each location differ in their building envelope and building system characteristics. Table 3-1 summarized all NZERTF building specifications and systems. Similarly, Table A-2, Table A-3, and Table A-4 listed in the Appendix section provide parameter assumptions for the building systems and building specifications for Zone 3 and Zone 4 (except the Marine climate zone) established under 2006, 2009, 2012, and 2015 IECC. Comparing the NZERTF specifications to those from the most recent IECC edition reveals that the net-zero energy design is significantly different from any of the code-compliant designs across all the building categories. The building envelope of the net-zero energy design has better thermal performance relative to all of the code-compliant designs given its use of higher efficiency windows, improved wall framing techniques, and more insulation. The HVAC, DHW, and lighting systems are also more energy-efficient.

Figure 4-9 shows the annual energy savings (kWh) from the NZERTF relative to a location's code-compliant design. Energy savings increase as you move west across the climate zone. Cities located in Oklahoma, Kansas, and portions of Texas realize the largest energy savings, ranging between $21559 \mathrm{kWh}$ to $25647 \mathrm{kWh}$ annually. The northeast portion of the region and along the east coast realize the least amount of energy savings.

\footnotetext{
${ }^{3}$ US Department of Energy (DOE) (2015). "Status of State Energy Code Adoption." from https://www.energycodes.gov/status-state-energy-code-adoption.
} 


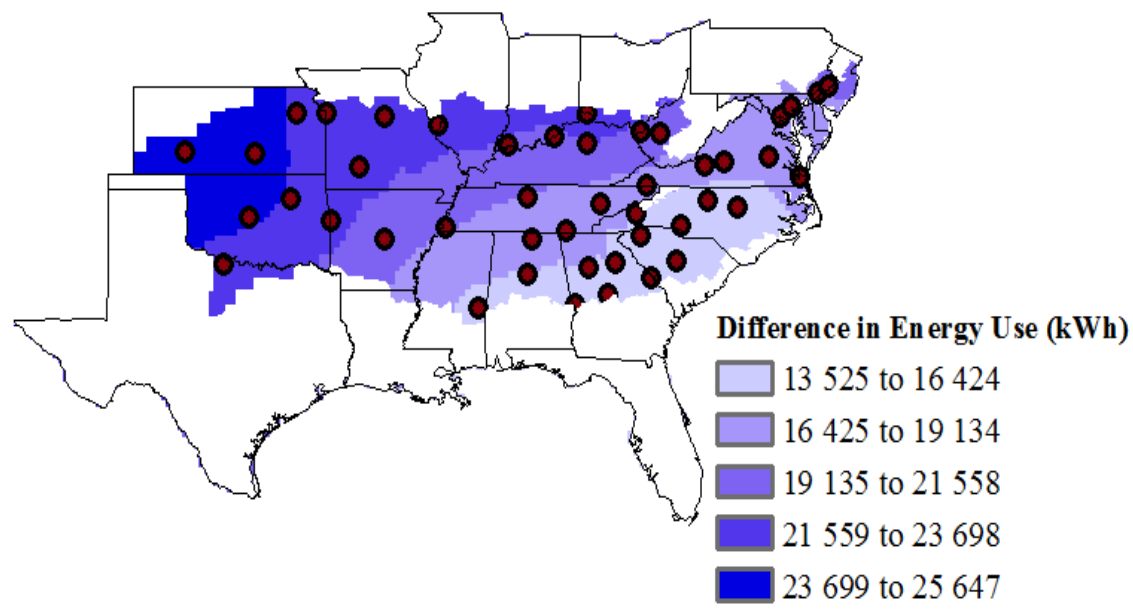

\section{Figure 4-9 Average Energy Savings (Difference in Energy Use) by Switching from the Code-Compliant to NZERTF Building Design (10-year Study Period)}

One key driver of the results is the variation in states codes throughout the zone which has considerable impacts on consumption behavior. Kansas and Oklahoma, for example, both have adopted codes older than the 2009 IECC (assumed to be 2006 IECC for this analysis). Cities in these states observe the largest of differences in energy use with annual consumption differences ranging from $21559 \mathrm{kWh}$ to 25647 . The 2006 edition of the IECC is far less energy-efficient than newer editions of the code - therefore, significant reductions in energy use as witnessed in Figure 4-9 are to be expected when switching from 2006 IECC to the NZERTF building specifications. Conversely, cities in states that have adopted newer editions of the IECC are likely to witness smaller consumption gaps as a result of gradual improvements in building efficiency. For example, North Carolina and Virginia adhere to the 2012 IECC and cities in these states observe average annual consumption savings of $19134 \mathrm{kWh}$ or less.

Another driver is the difference in local climatic conditions. For example, both Georgia and Indiana currently adhere to the 2009 edition of the IECC. Simulation results show that because Indiana faces a higher number of HDDs, on average, than Georgia, its overall energy use will be higher. As was discussed in Section 4.1, the improvement implemented in the building thermal envelope of the NZERTF reduces the amount of energy needed to satisfy household heating loads - with savings increasing as the local climate conditions grow colder.

Figure 4-10 further supports the above findings by revealing that: (1) switching from the codecompliant design to the NZERTF design significantly lowers the home's heating load, but not so much the cooling load; and (2) the absolute changes in energy consumption as a result of designing to reach net-zero energy in heating dominated locations are likely to be larger relative to areas that typically face a much lower number of HDDs. In Section 4-1, we discussed the limited variability in the thermal performance of the NZERTF throughout the climate zone as a result of its high level of efficiency. Figure 4-10 validates this previous discovery by showing 
that the NZERTF has small changes in heating- and cooling-based electricity consumption because of its exceptional thermal performance and higher efficiency equipment relative to the alternative IECC designs, which show a lot more variation across locations, primarily driven by heating.

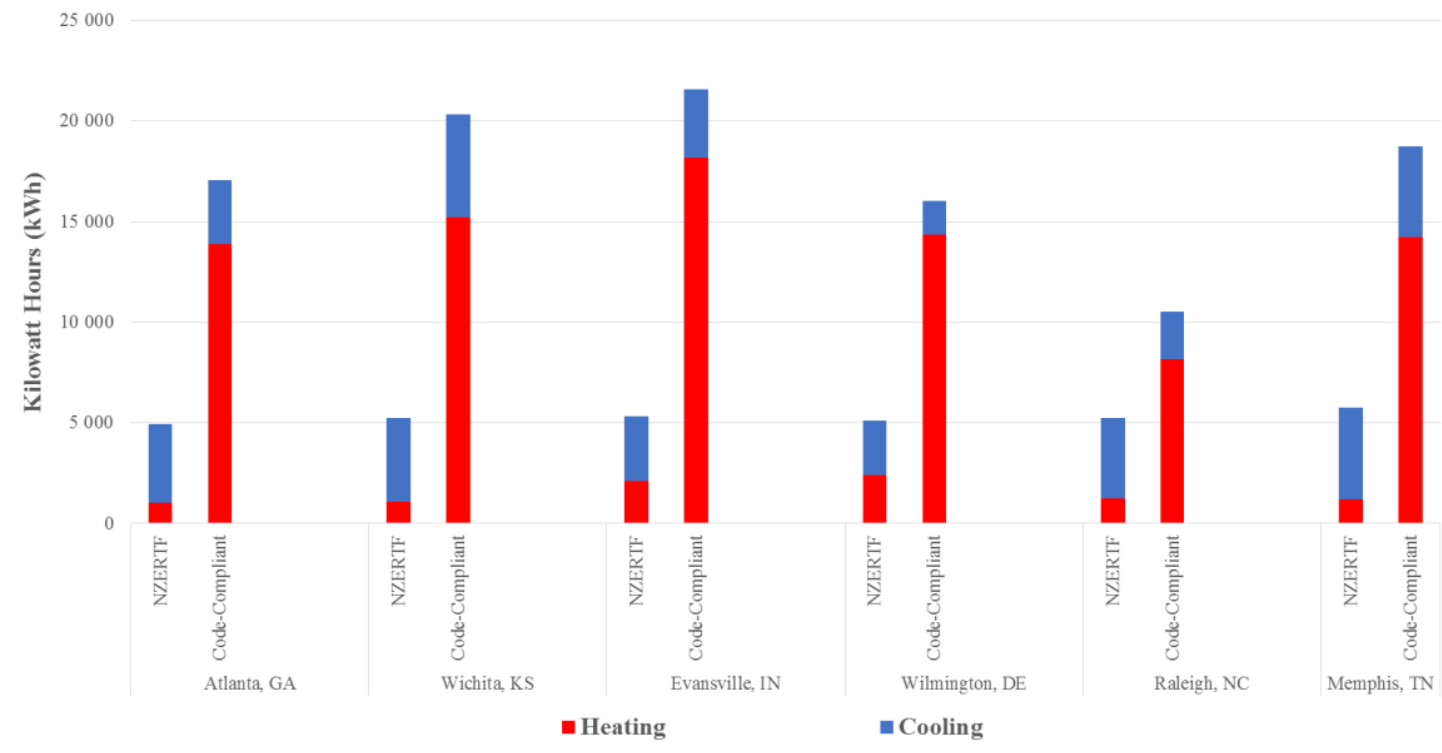

\section{Figure 4-10 Average Electricity Use for Satisfying the Heating and Cooling Loads of the NZERTF and Code-Compliant Building Designs}

The difference in net production determines the overall energy performance of the NZERTF as compared to code-compliant alternatives. It is calculated by adding the differences in electricity use and on-site solar electricity generation. A kriging map of the differences in net production levels (Figure 4-11) reveals that the net production differences are consistently negative throughout the entire zone, highlighting the fact that the NZERTF, on average, consistently performs better than a comparable, code-compliant alternative no matter where it is located in the climate zone. Additionally, these differences continue to widen the further west in the zone the building is located. The largest differences are observed in Kansas and Oklahoma with the average differences in net production falling within the $-40838 \mathrm{kWh}$ to $-45839 \mathrm{kWh}$ range. Similar to our consumption difference measures, it is evident once again that the NZERTF design performs better than a comparable, code-compliant alternative the further west it is located because of the combination of greater production and a lower efficiency requirements in the state's current building energy code. 


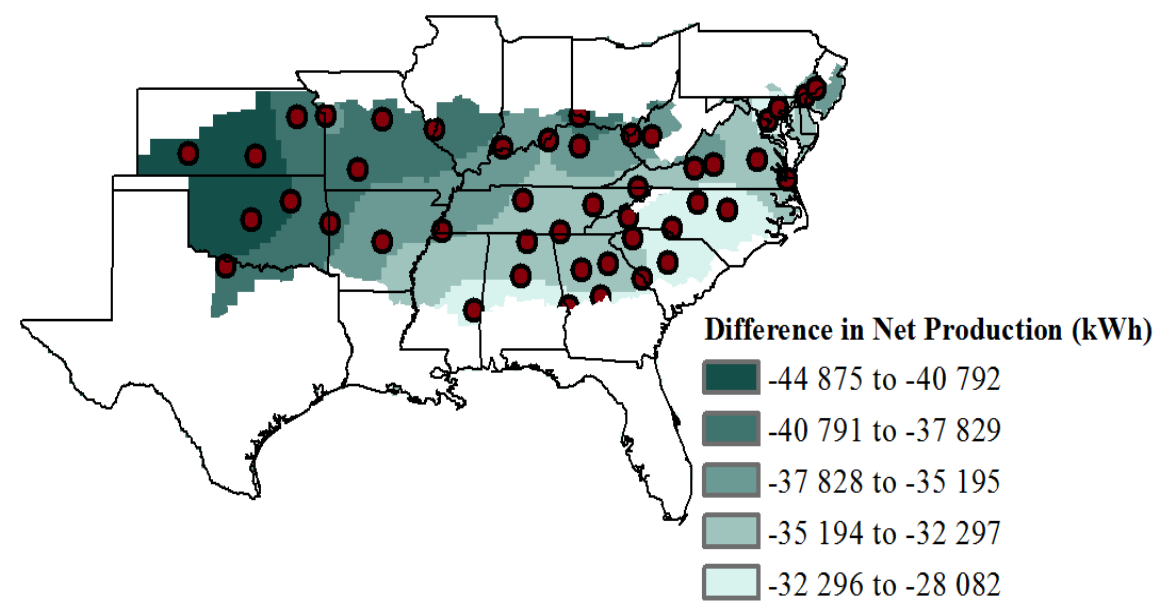

\section{Figure 4-11 Difference in Average Annual Net Production Levels between the NZERTF and Code-Compliant Building Designs}

\subsection{A Comparison of the Economic Performances for the NZERTF and Comparable Code-Compliant Design}

Given the significant differences between the two building structures, building components, and levels of energy efficiency, large cost disparities are likely to exist. In this section, we compare the economic performance of the two building designs based on differences in construction costs, energy costs, and life-cycle costs. Figure 4-12 provides an illustration of the differences in the average (a) construction costs and (b) total energy costs for a 10-year study period. Similar to Figure 4-5, visible trends in Figure 4-12(a) suggest that the differences in average construction costs increase the further north in the climate zone the house is located. Pennsylvania, Delaware, and portions of Missouri and Illinois realize observe the largest disparities in construction costs with cost differences ranging between $\$ 102246$ and \$109 558. The significant cost disparities in these areas are primarily driven by the mandated IECC edition adoptions in these states and/or the state average construction costs. Homes built to newer editions of the IECC are likely to be more expensive to build as they require additions to the building envelope and more expensive, higher efficiency equipment.

Unlike Figure 4-12(a), Figure 4-12(b) shows no apparent trends in the differences in energy costs across the climate zone. The smallest differences ( $\$ 23750$ to $-\$ 31587$ ) are found in parts of the southeast portion of the climate zone and along the east coast - Arkansas, Mississippi, Alabama, Georgia, South Carolina, North Carolina, Tennessee, Virginia, Kentucky, New Jersey and Pennsylvania. 
(a)

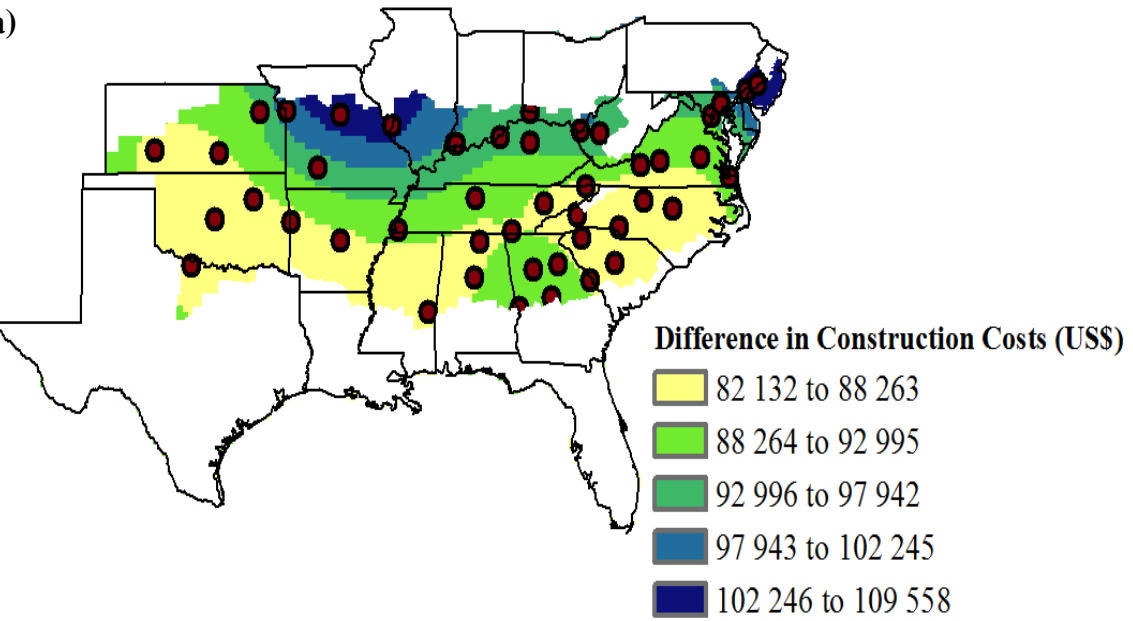

(b)

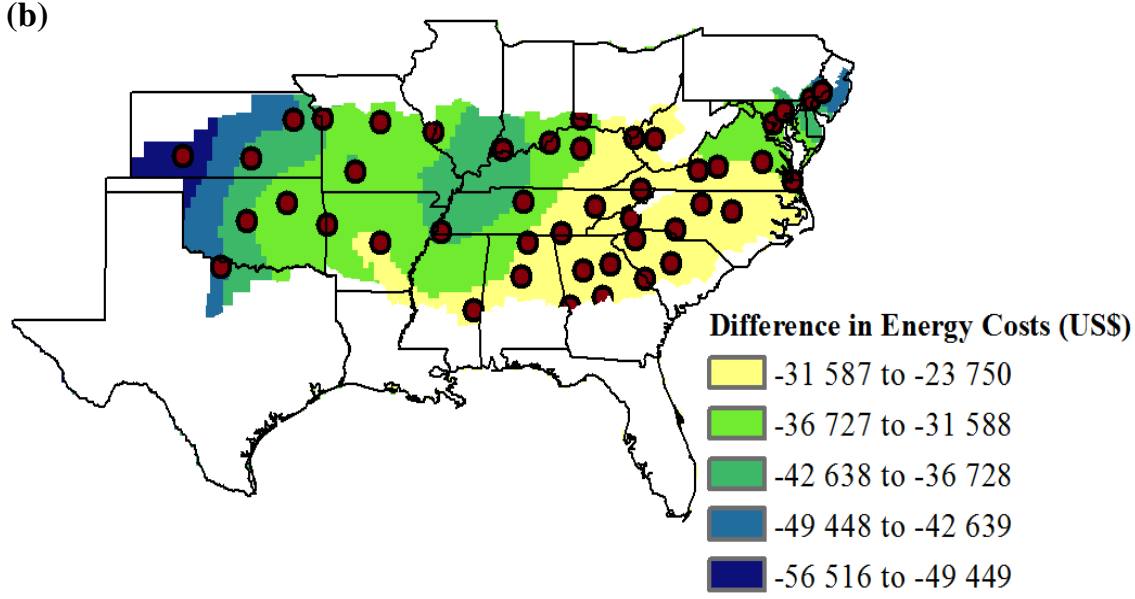

Figure 4-12 Difference in (a) Average Construction Costs and (b) Energy Costs between the NZERTF and Code-Compliant Building Designs

To shed light on how the two building design types differ in regards to economic feasibility across the climate zone we refer to average net savings calculations. Figure 4-13 shows that Net Savings (assuming a 10-year study period) are negative throughout most of the climate zone, implying that the NZERTF design is not a cost-effective alternative to comparable, codecompliant designs in these areas. The net-zero design is, however, an economically viable option (Net Savings greater than 0) in portions of Kansas, Oklahoma, Texas, Tennessee, Kentucky, Delaware, and Pennsylvania. According to Figure 4-13, the NZERTF is least likely to be costeffective in North Carolina and West Virginia. However, the additional present value cost is roughly $\$ 10$ 000. Other benefits of a net-zero energy home, such as decreased reliability on the electricity grid, social status, or lower environmental footprint, could carry a large enough value by some homeowners to make the NZERTF design preferrable to a code compliant design. 


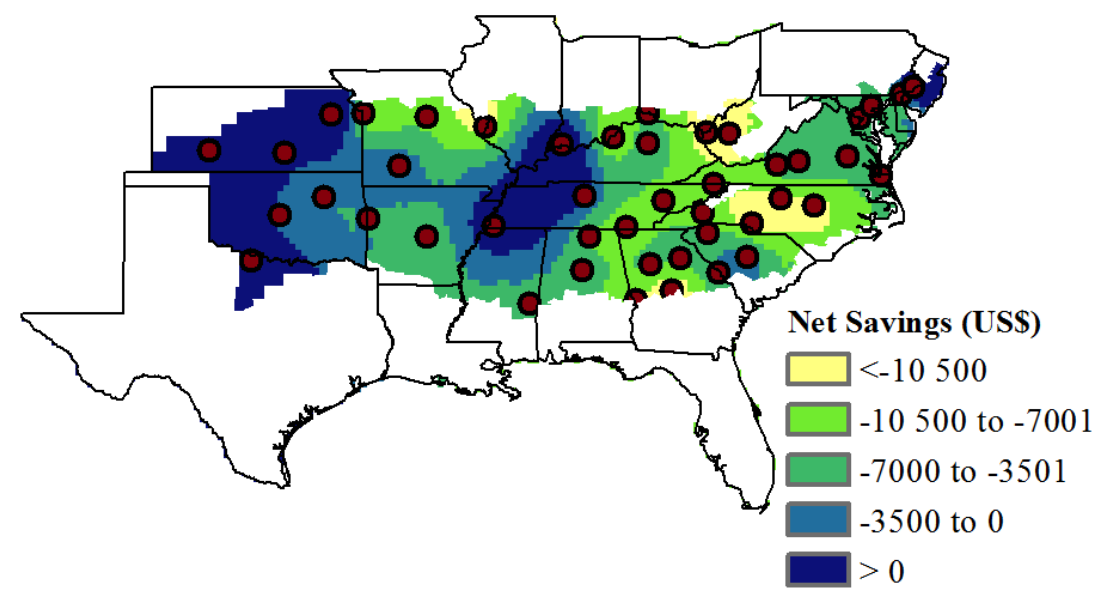

Figure 4-13 Net Savings (10-Year Study Period) 


\section{Discussion, Limitations, and Further Research Opportunities}

In this study, we rely on E+ whole-building energy simulations and life-cycle costing methods to: (1) observe the average differences in energy and economic performance of the NZERTF design across the Mixed-Humid Climate Zone based on 45 different locations; and (2) compare the average NZERTF energy and economic performance to that of a code-compliant alternative throughout the zone. Energy performance measures are based on annual energy consumption, solar PV generation, and net energy production. Measures for economic performance include construction costs, energy costs, LCC, and net savings. Average estimates for the entire climate zone are derived based on an interpolation method known as "kriging". Section 5.1 and Section 5.2 will discuss many of the key findings from the analysis. Section 5.3 discusses the research limitation and future research opportunities.

\subsection{Energy and Economic Performance of the NZERTF across the Mixed-Humid Climate Zone}

The largest energy consumers are found in states located in the western portion of the MixedHumid Climate Zone (i.e. Oklahoma, Kansas, Missouri, Arkansas, and Mississippi,) with average consumption falling within $12622 \mathrm{kWh}$ to $12865 \mathrm{kWh}$ each year. Portions of South Carolina, North Carolina, West Virginia, Virginia, Tennessee, and Kentucky realize the least level of consumption with annual consumption levels between $11666 \mathrm{kWh}$ and $11907 \mathrm{kWh}$. Variations in consumption across the climate zone are largely explained by the differences in heating and cooling loads. The highest electricity consumers generally have either a significantly greater number of HDDs or both HDDs and CDDs compared to other portions of the zone.

North Carolina along with states located in the northeast portion of the Mixed-Humid zone realize annual energy consumption levels within the $11689 \mathrm{kWh}$ to $12206 \mathrm{kWh}$ range. For states in the northeast, lower consumption is directly related to the thermal performance of the NZERTF. Despite the region facing cooler temperatures for larger portions of the year compared to other portions of the zone, the design's "tight" and heavily insulated building envelope significantly lowers total household electricity use by reducing the energy needed to satisfy the large heating loads that are characteristic of the area. Cooling-based electricity will play a much larger role in total energy use by the home than heating-based electricity. The combination of lower electricity demands for both heating and cooling result in the low consumption found in this region.

Yearly on-site solar PV generation is largely driven by a combination of three factors: the home's latitudinal/longitudinal location, the orientation and tilt of the roof-mounted system, and the average amount of cloud cover in a given location. Alabama, Georgia, and South Carolina, on average, are the second largest solar electricity producers with average production largely falling between $16178 \mathrm{kWh}$ and $16880 \mathrm{kWh}$ each year. Production in these areas is primarily influenced by the location and system positioning. Its fixed orientation (true south) and tilt (18.4 
from the horizontal) leads to better performance in the southern portions of the zone. Also, higher Global Horizontal Irradiance (GHI) levels in the south improve its production capabilities. Average production is greatest in portions of the zone that receive the least amount of cloud cover. Texas, Oklahoma, and Kansas, on average, produce at least $16374 \mathrm{kWh}$ annually.

NZERTF homeowners will be a consistent net producer throughout the entire Mixed-Humid climate zone. Illinois, Indiana, Kentucky, Maryland, Pennsylvania, and Delaware are the smallest net producers with average annual production levels of $3890 \mathrm{kWh}$ or less. Like PV generation, Texas, Oklahoma, and Kansas are the largest net producers. The high efficiency of the NZERTF design ensures that its energy use remains somewhat consistent under different local weather conditions. Its solar PV production, however, is far more sensitive to differences in local climatic conditions.

Compared to a less energy-efficient, state code-compliant design, the additional cost to the homeowner of incorporating energy-efficient measures and systems considerably increases the cost of constructing a net-zero design. Building the NIST NZERTF in the Mixed-Humid climate zone is most costly if built in Missouri, Indiana, or Kentucky. It becomes more economically viable to construct the home the further south in the climate zone it is located.

\subsection{Comparing the Energy and Economic Performance of the NZERTF to a Comparable Code-Compliant Design}

The portions of Oklahoma, Kansas, and Texas located in the Mixed-Humid climate zone realize the greatest differences in energy use between the two design types, with differences falling between $21559 \mathrm{kWh}$ and $25647 \mathrm{kWh}$. Consumption disparities are the smallest in the northeast portion of the climate zone and along the east coast. The unexpected trends in consumption differences are the result of: (1) variations in the IECC editions adopted by each state; and (2) differences in local climatic conditions. States having adopted older editions of the IECC have larger differences in energy use between the NZERTF and code-compliant designs, than states adopting newer code editions. Heating-dominated states realize greater savings by designing to reach net-zero than those adopting similar code editions that are less heating-dominated.

Differences in net energy production indicate how much better the energy performance of the NZERTF is relative to a code-compliant alternative. As revealed by the negative production differences, the NZERTF consistently performs better than the code-compliant alternative in all portions of the Mixed-Humid Climate Zone. The widening of the net production gap the further west the home is located suggests that the NZERTF performance becomes increasingly better the further west in the zone the home is located.

The enhanced energy-efficiency of the NZERTF over all code-compliant design alternatives makes it significantly more costly to build and greatly lowers electricity expenditures. The most considerable differences in average construction costs occur in Pennsylvania, Delaware, and parts of Missouri and Illinois. The greatest potential for energy savings by operating the 
NZERTF design in place of a code-compliant alternative will occur in the western most portion of the climate zone.

For a 10-year study period, the NZERTF proves to be an economically viable alternative to a code-compliant design in large portions of Kansas, Oklahoma, Texas, Tennessee, Kentucky, Delaware, and Pennsylvania. The federal tax credit linked to the integrated $10.2 \mathrm{~kW}$ roofmounted solar PV system lowers the LCC in these areas enough to make designing to reach netzero cost effective.

\subsection{Limitations and Future Research}

The analysis in this study is limited in scope and scale. Future research should take into consideration: (1) alternative net-zero energy building designs; (2) weather data for more locations within the Mixed-Humid Climate Zone; (3) other Building America Climate Zones and locations; (4) alternative assumption and parameter values; and (5) additional cost data and approaches.

By using the same NZERTF simulation model for each of the 45 locations in the Mixed-Humid Climate Zone, our study assumes that the appropriate building geometry, specifications and systems are similar in each of these locations. This is likely not representative of the housing market as typical home designs can differ significantly from location to location despite being in the same climate zone. For example, homes in the northeast portion of the Mixed-Humid Climate Zone will likely be multi-story homes and have less square footage; whereas homes in the most western portion of the zone are likely going to have more square footage and fewer stories. The same is true in regards to building specifications. Net-zero energy homes built in areas realizing a greater number of HDDs will likely incorporate more insulation in the construction of their building envelope than those in cooler portion of the climate zone. Future work should consider alternative net-zero energy designs that are more representative of the types of single-family constructions found in each city.

Use of the kriging method allows us to interpolate and estimate average impacts given our 45 data points. However, these rough estimates can be improved upon with the use of more data points. The inclusion of more data points by way of use of weather files for these additional locations should be considered in later work. Additionally, future research should compare netzero energy building performance in other Building America Climate Zones in an effort to broaden the scope of our work.

All the first and future costs associated with constructing and operating a building are included, but were derived based on several assumptions. Future research should consider alternatives to these assumptions to produce a more robust analysis. For example, LCCs are computed in this study using a $3 \%$ discount rate. Other discount rates should be considered. This analysis assumes that the costs associated with the construction of the house are paid up front although the use of financing is typical of home buyers. Alternative financing options must be considered in later 
work. Similarly, future work must consider financing and/or leasing options for alternative onsite renewable energy systems. Energy cost calculations in this study are based on state average electricity prices and net metering rates that are equivalent to electricity prices. However, both the local electricity rates and the compensation for net metering are likely to differ from state average rates in both magnitude and rate structure, and are likely to change in the future due to increased levels of distributed energy. Local electricity prices and alternative compensation structures should be considered in future work. We have included only the $30 \%$ federal tax credit for the addition of the roof mounted solar PV system. Future analyses should also account for current state and local incentives for renewable energy generations systems. These additional incentives can have significant impacts on the economic performance of the home.

A 10-year study period was assumed for computing LCC based on current statistics suggesting that the average homeowner only lives in a residence for roughly 13 years. The chosen study period length can significantly impact the economics of the house. Because the economics are a major driver behind investment decisions in low-energy homes, LCCs based on shorter and longer study periods should be considered in future research in an effort to better understand the relationship between investment in low-energy buildings and the assumed amount of time the homeowner will live in the house.

The LCC methodology states that the residual value of a building at the end of the study period is calculated based on a linear depreciation of the initial house value. Because there is some ambiguity in the market valuation of reductions in energy use, alternative approaches to measuring the resale value needs to be taken into consideration in the future. The NZERTF design includes a number of measures to improve the energy-efficiency of the home. There are also a number of non-energy related amenities that result in a LEED Platinum Certification that may add value at the time of resale but were ignored in this analysis. Future research should consider the value of both the energy related features and non-energy related features of the NZERTF when completing a LCC analysis for the NZERTF design.

The underlying cost data used in this study is based on a publically available database that is becoming outdated. The database itself is becoming outdated. For example, the price of installed solar PV systems has continued to decrease since the cost data implemented in this study was published. The use of more up-to-date cost data should be considered in future research. 


\section{References}

ASHRAE Handbook (2013). Fundamentals 2013. Atlanta, GA.

ASTM International (2010). E779-10 Standard Test Method for Determining Air Leakage Rate by Fan Pressurization.

ASTM International (2012). ASTM Standards on Building Economics: 7th Edition. West Conshohocken, PA, ASTM International.

Barbose, G., et al. (2014). Tracking the Sun VII: An Historical Summary of the Installed Price of Photovoltaics in the United States from 1998 to 2013. Berkeley, CA, Lawrence Berkeley National Laboratory.

Bohling, G. (2005). "Kriging." Retrieved 10/01/2015, from

http://people.ku.edu/ gbohling/cpe940/Kriging.pdf.

Building Science Corportation (BSC) (2009). "65\% Net-Zero Energy Residential Test Facility Construction Documents Set." 2012.

Dietrich, U., et al. (2013). Zero-Energy-Buildings in Different Climates: Design Strategies, Simulation and Prognosis METHOD for Energy Demand. 13th Conference of International Building Performance Simulation Association, Chambery, France.

Emrath, P. (2013). "Latest Study Shows Average Buyer Expected to Stay in a Home 13 Years." Retrieved September 24, 2015, from http://eyeonhousing.org/2013/01/latest-study-showsaverage-buyer-expected-to-stay-in-a-home-13-years/.

Faithful+Gould (2011). Residential Energy Efficiency Measures: Location Factors, National Renewable Energy Laboratory.

Faithful+Gould (2012). Residential Energy Efficiency Measures: Prototype Estimate and Cost Data Revision 6.0, National Renewable Energy Laboratory.

Fanney, A. H., et al. (2015). "Net-zero and beyond! Design and performance of NIST's net-zero energy residential test facility." Energy and Buildings 101: 95-109. 
Fuller, S. and S. Petersen (1996). Life-Cycle Costing Manual for the Federal Energy Management Program, 1995 Edition. NIST handbook 135. National Institute of Standards and Technology.

Hong, T., et al. (2013a). A Sensitivity Study of Building Performance Using 30-year Actual Weather Data. 13th Conference of International Building Performance Simulation Association Chambéry, France.

Hong, T., et al. (2013b). "A Fresh Look at Weather Impact on Peak Electricity Demand and Energy Use of Buildings using 30-year Actual Weather Data." Applied Energy 111: 333-350.

Kneifel, J. (2012). Annual Whole Building Energy Simulation of the NIST Net Zero Energy Residential Test Facility Design. U.S. Department of Commerce, National Institute of Standards and Technology.

Kneifel, J. (2013). "Benefits and Costs of Energy Standard Adoption in New Commercial Buildings: National Summary." NIST Special Publication 1161.

Kneifel, J. (2013a). "Benefits and Costs of Energy Standard Adoption in New Commercial Buildings." NIST Special Publication 1147.

Kneifel, J. and P. Lavappa (2015). "Building Industry Reporting and Design for Sustainability (BIRDS) New Residential Database Technical Manual." NIST Technical Note 1878.

Kneifel, J. and E. O'Rear (2015). "Sustainability Performance of the NIST Net-Zero Energy Residential Test Facility Relative to a Maryland Code-Compliant Design." NIST Special Publication 1187.

Kneifel, J. and E. O'Rear (2015b). "Benefits and Costs of Energy Standard Adoption for New Residential Buildings: National Summary." NIST Special Publication 1194.

Kneifel, J. and E. O'Rear (2015c). Assessing the Impacts of Typical Weather Year Data vs. Multi-year Weather Data on Net-Zero Energy Building Simulations, National Institute of Standards and Technology.

Kneifel, J., et al. (2015). "Simulated versus Measured Energy Performance of the NIST Net Zero Residential Test Facility Design." NIST Special Publication 1182. 
Lam, J. C., et al. (2006). "Impacts of Lighting Density on Heating and Cooling Loads in Different Climates in China." Energy Conversion and Management 47(13): 1942-1953.

Lam, J. C., et al. (2008). "Building Energy Efficiency in Different Climates." Energy Conversion and Management 49(8): 2354-2366.

Lstiburek, J. and P. Eng (2010). "Advanced Framing." Insight 30: 1-7.

National Renewable Energy Laboratory (NREL) (2015). "Solar Maps." from http://www.nrel.gov/gis/solar.html.

Pettit, B. and C. Gates (2014). "Design Challenges of the NIST Net Zero Energy Residential Test Facility." NIST Technical Note.

Rushing, A., et al. (2014). Energy Price Indices and Discount Factors for Life-Cycle Cost Analysis - 2014, Annual Supplement to NIST Handbook 135. National Institute of Standards and Technology.

U.S. Department of Energy (DOE) (2015). "Building America: Bringing Building Innovations to Market." from http://energy.gov/eere/buildings/building-america-bringing-building-innovationsmarket.

U.S. Department of Energy (DOE) (2015). EnergyPlus Simulation SoftwareVersion 8.3.0, Building Technologies Program (BTP).

U.S. Department of Energy (DOE) (2015). "Weather Data Sources." from http://apps1.eere.energy.gov/buildings/energyplus/weatherdata_sources.cfm.

US Department of Energy (DOE) (2015). "Status of State Energy Code Adoption." from https://www.energycodes.gov/status-state-energy-code-adoption.

US Energy Information Administration (EIA) (2015). "How much energy is consumed in residential and commercial buildings in the United States?". from http://www.eia.gov/tools/faqs/faq.cfm?id=86\&t=1.

Wilson, E., et al. (2014). 2014 Building America House Simulation Protocols. Golden, CO, National Renewable Energy Laboratory (NREL). 
Yang, L., et al. (2008). "Building Energy Simulation using Multi-years and Typical Meteorological Years in Different Climates." Energy Conversion and Management 49(1): 113124.

Zhang, K. and N. Zhu (2013). "Comparison and Analysis of Energy Consumption of Energyefficient Office Buildings in Different Climate Regions in China: Case Studies." Frontiers in Energy 7(3): 399-405. 


\section{A Appendix}

Table A-1 Selected Locations in the Building America Mixed-Humid Climate Zone

\begin{tabular}{|c|c|c|c|}
\hline \multicolumn{2}{|l|}{ Climate Zone 3A } & \multicolumn{2}{|l|}{ Climate Zone 4} \\
\hline State & City & State & City \\
\hline \multirow[t]{2}{*}{ Alabama } & Birmingham & $\mathrm{DC}$ & Washington \\
\hline & Huntsville & Delaware & Wilmington \\
\hline \multirow[t]{2}{*}{ Arkansas } & Fort Smith & Indiana & Evansville \\
\hline & Little Rock & Kansas & Dodge City \\
\hline \multirow[t]{5}{*}{ Georgia } & Athens & & Topeka \\
\hline & Atlanta & & Wichita \\
\hline & Augusta & Kentucky & Covington \\
\hline & Columbus & & Lexington \\
\hline & Macon & & Louisville \\
\hline Mississippi & Meridian & Maryland & Baltimore \\
\hline North Carolina & Charlotte & Missouri & Columbia \\
\hline \multirow[t]{2}{*}{ Oklahoma } & Oklahoma City & & Kansas City \\
\hline & Tulsa & & Springfield \\
\hline \multirow{2}{*}{ South Carolina } & Columbia & & St. Louis \\
\hline & Greenville & North Carolina & Asheville \\
\hline \multirow{12}{*}{$\begin{array}{l}\text { Tennessee } \\
\text { Texas }\end{array}$} & Memphis & & Greensboro \\
\hline & Fort Worth & & Raleigh \\
\hline & & Pennsylvania & Philadelphia \\
\hline & & Tennessee & Chattanooga \\
\hline & & & Knoxville \\
\hline & & & Nashville \\
\hline & & Virginia & Lynchburg \\
\hline & & & Norfolk \\
\hline & & & Richmond \\
\hline & & & Roanoke \\
\hline & & West Virginia & Charleston \\
\hline & & & Huntington \\
\hline
\end{tabular}


Table A-2 Building Specifications under the 2012 and 2105 IECC Editions

\begin{tabular}{|c|c|c|c|}
\hline Building Category & Specifications & 2015/2012 IECC (Climate Zone 3)* & 2015/2012 IECC (Climate Zone 4 except Marine)* \\
\hline Windows & $\begin{array}{l}\text { U-Factor } \\
\text { SHGC }\end{array}$ & $\begin{array}{c}1.99 \mathrm{~W} / \mathrm{m}^{2}-\mathrm{K}\left(0.35 \mathrm{Btu} / \mathrm{h} * \mathrm{ft}^{2}-\mathrm{F}\right) \\
0.25\end{array}$ & $\begin{array}{c}1.99 \mathrm{~W} / \mathrm{m}^{2}-\mathrm{K}\left(0.35 \mathrm{Btu} / \mathrm{h} \cdot \mathrm{ft}^{2}-\mathrm{F}\right) \\
0.40\end{array}$ \\
\hline $\begin{array}{l}\text { Framing and } \\
\text { Insulation }\end{array}$ & $\begin{array}{l}\text { Framing } \\
\text { Exterior Wall } \\
\text { Basement Wall } \\
\text { Roof/Ceiling } \\
\text { Assembly }\end{array}$ & $\begin{array}{c}5.1 \mathrm{~cm} \mathrm{x} 10.2 \mathrm{~cm}-40.6 \mathrm{~cm} \mathrm{OC}(2 \text { in } \mathrm{x} 4 \text { in }-16 \text { in } \mathrm{OC}) \\
\mathrm{R}_{\mathrm{SI}^{-}}-3.5 \text { or } \mathrm{R}_{\mathrm{SI}^{-}}-2.3+0.9(\mathrm{R}-20 \text { or } \mathrm{R}-13+5)^{* * \dagger} \dagger \\
\mathrm{R}_{\mathrm{SI}^{-}} 0.9(\mathrm{R}-5) \dagger \\
\text { Ceiling: } \mathrm{R}_{\mathrm{SI}^{-}}-6.7(\mathrm{R}-38)\end{array}$ & $\begin{array}{c}5.1 \mathrm{~cm} \times 10.2 \mathrm{~cm}-40.6 \mathrm{~cm} \mathrm{OC}(2 \text { in } \times 4 \text { in }-16 \text { in } \mathrm{OC}) \\
\mathrm{R}_{\mathrm{SI}^{-}}-3.5 \text { or } \mathrm{R}_{\mathrm{SI}^{-}}-2.3+0.9(\mathrm{R}-20 \text { or } \mathrm{R}-13+5)^{* * \dagger} \\
\mathrm{R}_{\mathrm{SI}^{-}}-1.8(\mathrm{R}-10) \dagger \\
\text { Ceiling: } \mathrm{R}_{\mathrm{SI}^{-}}-8.6(\mathrm{R}-49)\end{array}$ \\
\hline Infiltration & $\begin{array}{l}\text { Air Change Rate } \\
\text { Effective Leakage } \\
\quad \text { Area }\end{array}$ & $\begin{array}{c}3.00 \mathrm{ACH} 50 \\
1^{\text {st }} \text { Floor }=403.6 \mathrm{~cm}^{2}\left(62.6 \mathrm{in}^{2}\right) \\
2^{\text {nd }} \text { Floor }=368.1 \mathrm{~cm}^{2}\left(57.1 \mathrm{in}^{2}\right)\end{array}$ & $\begin{array}{c}3.00 \mathrm{ACH} 50 \\
1^{\text {st }} \text { Floor }=403.6 \mathrm{~cm}^{2}\left(62.6 \mathrm{in}^{2}\right) \\
2^{\text {nd }} \text { Floor }=368.1 \mathrm{~cm}^{2}\left(57.1 \mathrm{in}^{2}\right)\end{array}$ \\
\hline Lighting & Efficient Lighting (\%) & $75 \%$ efficient built-in fixtures & $75 \%$ efficient built-in fixtures \\
\hline HVAC & $\begin{array}{l}\text { Heating/Cooling } \\
\text { Outdoor Air**** }\end{array}$ & $\begin{array}{l}\text { Air-to-air heat pump (SEER 13/HSPF 7.7) } \\
\text { Min. Outdoor Air }(0.04 \mathrm{~m} 3 / \mathrm{s})\end{array}$ & $\begin{array}{l}\text { Air-to-air heat pump (SEER 13/HSPF 7.7) } \\
\text { Min. Outdoor Air (0.04 m3/s) }\end{array}$ \\
\hline $\begin{array}{l}\text { Domestic Hot } \\
\text { Water }\end{array}$ & $\begin{array}{l}\text { Water Heater } \\
\text { Solar Thermal }\end{array}$ & $189 \mathrm{~L}$ (50 gal) electric water heater (0.98 efficiency) & $189 \mathrm{~L}$ (50 gal) electric water heater (0.98 efficiency) \\
\hline Solar PV System & System Size & None & None \\
\hline \multicolumn{4}{|c|}{$\begin{array}{l}* \text { The insulation and fenestration requirements are similar for both the } 2012 \text { and } 2015 \text { IECC editions } \\
* * \text { Interior Wall Cavity + Exterior Continuous Insulation } \\
* * * \text { Minimum outdoor air requirements are based on ASHRAE } 62.2-2010 \\
+ \text { Units: } \mathbf{m}^{2} \mathbf{K} / \mathbf{W}\left(\mathbf{f t}^{2}-\mathbf{F} \cdot(\mathbf{B t u} / \mathbf{h})\right.\end{array}$} \\
\hline
\end{tabular}


Table A-3 Building Specifications under the 2009 IECC Edition (Climate Zone 3 and 4 except Marine)

\begin{tabular}{|c|c|c|c|}
\hline Building Category & Specifications & 2009 IECC (Climate Zone 3) & 2009 IECC (Climate Zone 4 except Marine) \\
\hline Windows & $\begin{array}{l}\text { U-Factor } \\
\text { SHGC }\end{array}$ & $\begin{array}{c}2.84 \mathrm{~W} / \mathrm{m}^{2}-\mathrm{K}\left(0.50 \mathrm{Btu} / \mathrm{h}^{*} \mathrm{ft}^{2}-\mathrm{F}\right) \\
0.30\end{array}$ & $\begin{array}{c}1.99 \mathrm{~W} / \mathrm{m}^{2}-\mathrm{K}\left(0.35 \mathrm{Btu} / \mathrm{h} \cdot \mathrm{ft}^{2}-\mathrm{F}\right) \\
0.60^{4}\end{array}$ \\
\hline $\begin{array}{l}\text { Framing and } \\
\text { Insulation }\end{array}$ & $\begin{array}{l}\text { Framing } \\
\text { Exterior Wall } \\
\text { Basement Wall } \\
\text { Roof/Ceiling } \\
\text { Assembly }\end{array}$ & $\begin{array}{c}5.1 \mathrm{~cm} \mathrm{x} 10.2 \mathrm{~cm}-40.6 \mathrm{~cm} \mathrm{OC}(2 \text { in } \mathrm{x} 4 \text { in }-16 \text { in } \mathrm{OC}) \\
\mathrm{R}_{\mathrm{SI}^{-}}-3(\mathrm{R}-13) \dagger \\
\mathrm{R}_{\mathrm{SI}^{-}}-0.9(\mathrm{R}-5) \dagger \\
\text { Ceiling: } \mathrm{R}_{\mathrm{SI}}-5.3(\mathrm{R}-30)\end{array}$ & $\begin{array}{c}5.1 \mathrm{~cm} \times 10.2 \mathrm{~cm}-40.6 \mathrm{~cm} \mathrm{OC}(2 \text { in } \times 4 \text { in }-16 \text { in } \mathrm{OC}) \\
\mathrm{R}_{\mathrm{SI}^{-}}-2.3(\mathrm{R}-13) \dagger \\
\mathrm{R}_{\mathrm{SI}^{-1}}-1.8(\mathrm{R}-10) \dagger \\
\text { Ceiling: } \mathrm{R}_{\mathrm{SI}^{-}}-6.7(\mathrm{R}-38)\end{array}$ \\
\hline Infiltration & $\begin{array}{l}\text { Air Change Rate } \\
\text { Effective Leakage } \\
\text { Area }\end{array}$ & $\begin{aligned} & 7.00 \mathrm{ACH}_{50} \\
1^{\text {st }} \text { Floor }= & 1473.3 \mathrm{~cm}^{2}\left(228.4 \mathrm{in}^{2}\right) \\
2^{\text {nd }} \text { Floor }= & 1343.3 \mathrm{~cm}^{2}\left(208.2 \mathrm{in}^{2}\right)\end{aligned}$ & $\begin{array}{c}7.00 \mathrm{ACH}_{50}{ }^{5} \\
1^{\text {st }} \text { Floor }=1473.3 \mathrm{~cm}^{2}\left(228.4 \mathrm{in}^{2}\right) \\
2^{\text {nd }} \text { Floor }=1343.3 \mathrm{~cm}^{2}\left(208.2 \mathrm{in}^{2}\right)\end{array}$ \\
\hline Lighting & Efficient Lighting (\%) & $50 \%$ efficient built-in fixtures & No Requirement ${ }^{6}$ \\
\hline HVAC & $\begin{array}{l}\text { Heating/Cooling } \\
\text { Outdoor Air* }\end{array}$ & $\begin{array}{c}\text { Air-to-air heat pump (SEER 13/HSPF 7.7) } \\
\text { Min. Outdoor Air }(0.04 \mathrm{~m} 3 / \mathrm{s})\end{array}$ & $\begin{array}{c}\text { Air-to-air heat pump (SEER 13/HSPF 7.7) } \\
\text { Min. Outdoor Air }(0.04 \mathrm{~m} 3 / \mathrm{s})\end{array}$ \\
\hline Solar PV System & System Size & None & None \\
\hline \multicolumn{4}{|c|}{$\begin{array}{l}* \text { Minimum outdoor air requirements are based on ASHRAE 62.2-2010 } \\
+ \text { Units: } \mathbf{m}^{2} \mathbf{K} / \mathbf{W}\left(\mathbf{f t}^{2}-\mathbf{F} \cdot(\mathbf{B t u} / \mathbf{h})\right.\end{array}$} \\
\hline
\end{tabular}


Table A-4 Building Specifications under the 2006 IECC Edition (Climate Zone 3 and 4 except Marine)

\begin{tabular}{|c|c|c|c|}
\hline $\begin{array}{l}\text { Building } \\
\text { Category }\end{array}$ & Specifications & 2006 IECC (Climate Zone 3) & 2006 IECC (Climate Zone 4 except Marine) \\
\hline Windows & $\begin{array}{l}\text { U-Factor } \\
\text { SHGC }\end{array}$ & $\begin{array}{c}2.27 \mathrm{~W} / \mathrm{m}^{2}-\mathrm{K}\left(0.40 \mathrm{Btu} / \mathrm{h}^{*} \mathrm{ft}^{2}-\mathrm{F}\right) \\
0.40\end{array}$ & $\begin{array}{c}3.69 \mathrm{~W} / \mathrm{m}^{2}-\mathrm{K}\left(0.65 \mathrm{Btu} / \mathrm{h} \cdot \mathrm{ft}^{2}-\mathrm{F}\right) \\
0.60^{7}\end{array}$ \\
\hline $\begin{array}{l}\text { Framing and } \\
\text { Insulation }\end{array}$ & $\begin{array}{c}\text { Framing } \\
\text { Exterior Wall } \\
\text { Basement Wall } \\
\text { Roof/Ceiling Assembly }\end{array}$ & $\begin{array}{c}5.1 \mathrm{~cm} \times 10.2 \mathrm{~cm}-40.6 \mathrm{~cm} \mathrm{OC}(2 \text { in } \times 4 \text { in }-16 \text { in } \mathrm{OC}) \\
\mathrm{R}_{\mathrm{SI}^{-}}-2.3(\mathrm{R}-13) \dagger \\
\mathrm{R}_{\mathrm{SI}^{-}}-0.0(\mathrm{R}-0) \dagger \\
\text { Ceiling: } \mathrm{R}_{\mathrm{SI}^{-}}-5.3(\mathrm{R}-30)\end{array}$ & $\begin{array}{c}5.1 \mathrm{~cm} \times 10.2 \mathrm{~cm}-40.6 \mathrm{~cm} \mathrm{OC}(2 \text { in } \times 4 \text { in }-16 \text { in } \mathrm{OC}) \\
\mathrm{R}_{\mathrm{SI}^{-}}-2.3(\mathrm{R}-13) \dagger \\
\mathrm{R}_{\mathrm{SI}^{-}}-1.8(\mathrm{R}-10) \dagger \\
\text { Ceiling: } \mathrm{R}_{\mathrm{SI}^{-}}-6.7(\mathrm{R}-38)\end{array}$ \\
\hline Infiltration & $\begin{array}{l}\text { Air Change Rate }{ }^{8} \\
\text { Effective Leakage Area }\end{array}$ & $\begin{array}{c}7.00 \mathrm{ACH}_{50} \\
1^{\text {st }} \text { Floor }=1473.3 \mathrm{~cm}^{2}\left(228.4 \mathrm{in}^{2}\right) \\
2^{\text {nd }} \text { Floor }=1343.3 \mathrm{~cm}^{2}\left(208.2 \mathrm{in}^{2}\right)\end{array}$ & $\begin{aligned} & 7.00 \mathrm{ACH}_{50} \\
1^{\text {st }} \text { Floor }= & 1473.3 \mathrm{~cm}^{2}\left(228.4 \mathrm{in}^{2}\right) \\
2^{\text {nd }} \text { Floor }= & 1343.3 \mathrm{~cm}^{2}\left(208.2 \mathrm{in}^{2}\right)\end{aligned}$ \\
\hline Lighting & Efficient Lighting $(\%)^{9}$ & No Requirement & No Requirement \\
\hline HVAC & $\begin{array}{l}\text { Heating/Cooling } \\
\text { Outdoor Air* }\end{array}$ & $\begin{array}{l}\text { Air-to-air heat pump (SEER 13/HSPF 7.7) } \\
\text { Min. Outdoor Air }(0.04 \mathrm{~m} 3 / \mathrm{s})\end{array}$ & $\begin{array}{l}\text { Air-to-air heat pump (SEER 13/HSPF 7.7) } \\
\text { Min. Outdoor Air }(0.04 \mathrm{~m} 3 / \mathrm{s})\end{array}$ \\
\hline $\begin{array}{l}\text { Domestic Hot } \\
\text { Water }\end{array}$ & $\begin{array}{l}\text { Water Heater } \\
\text { Solar Thermal }\end{array}$ & $189 \mathrm{~L}$ (50 gal) electric water heater (0.98 efficiency) & $189 \mathrm{~L}$ (50 gal) electric water heater (0.98 efficiency) \\
\hline Solar PV System & System Size & None & None \\
\hline
\end{tabular}

${ }^{4}$ The 2009 edition of the IECC does not require a minimum SHGC. Our assumption of a 0.60 SHGC is based on

5 The 2009 edition of the IECC does not require a minimum Air Change Rate. For practicality, we assume a rate of $7.00 \mathrm{ACH}_{50}$.

${ }^{6}$ The 2009 edition of the IECC does not require a minimum level of efficiency for built-in light fixtures. For practicality, we follow the Building America House Simulation Protocols (2014) which establishes a benchmark lighting budget for new residential construction. It requires $66 \%$ of all lamps to be incandescent, $21 \%$ are compact fluorescent lamps (CFLs), and $13 \%$ are T-8 linear fluorescent.

7 The 2006 edition of the IECC does not require a minimum SHGC. We assume a SHGC of 0.60 SHGC because

${ }^{8}$ The 2006 edition of the IECC does not establish a minimum Air Change Rate. For practicality, we assume that the minimum air change rate is 7.00 ACH ${ }_{50}$ for all climate zones 3 and 4 (except Marine).

${ }^{9}$ The 2009 edition of the IECC does not require a minimum level of efficiency for built-in light fixtures. For practicality, we follow the Building America House Simulation Protocols (2014) which establishes a benchmark lighting budget for new residential construction. It requires $66 \%$ of all lamps to be incandescent, $21 \%$ are compact fluorescent lamps (CFLs), and $13 \%$ are T-8 linear fluorescent. 
